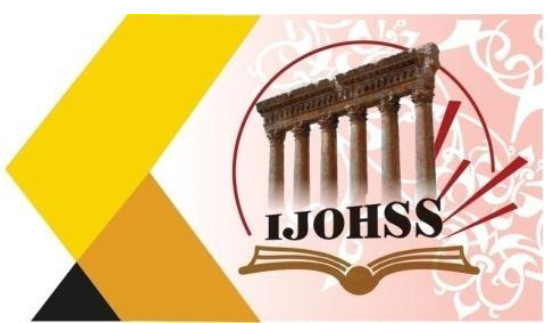

\title{
استراتيجية التفاوض بين الزوجين وانعكاسه على إدارة الضغوط الاسرية الئن
}

\author{
د. دإيمان شعبان أحمد

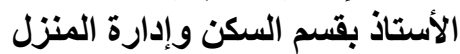

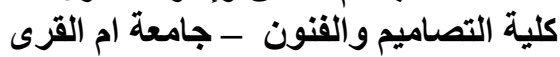

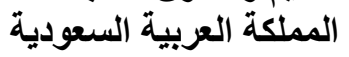

يمدف البحث الحالي الي دراسـة العلاقة بين استر اتيجيات التفاوض بين الزوجين و الضـغوط الاسترية و استخدم

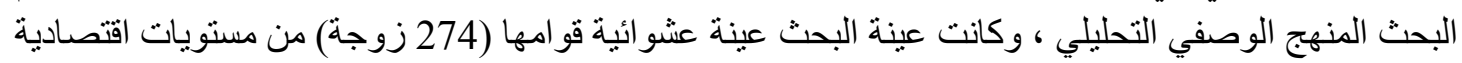

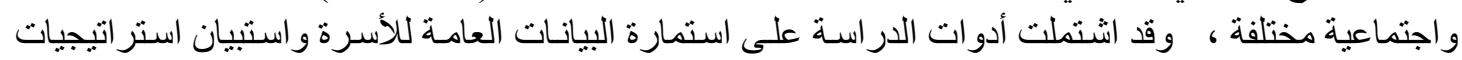

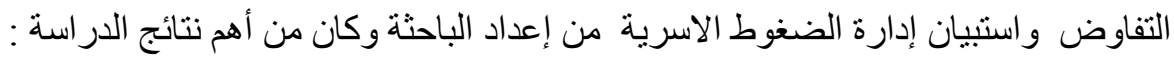

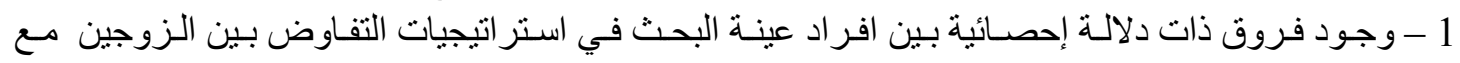

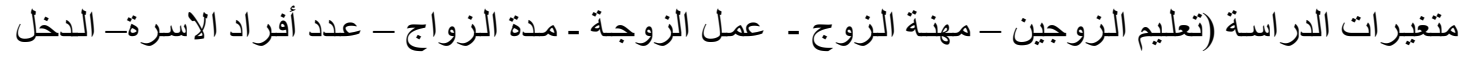

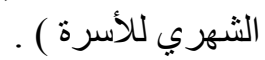

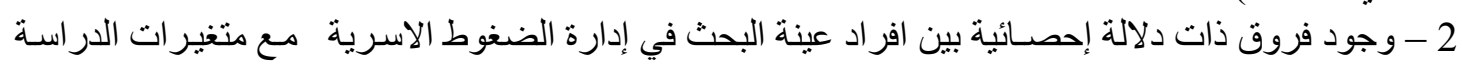

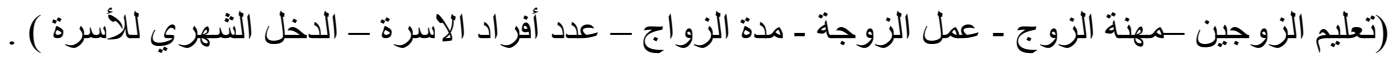

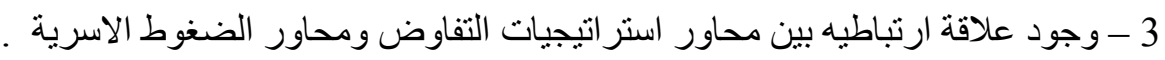

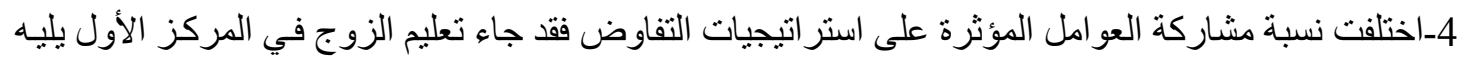

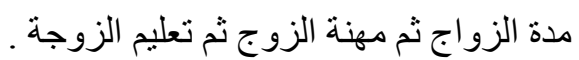

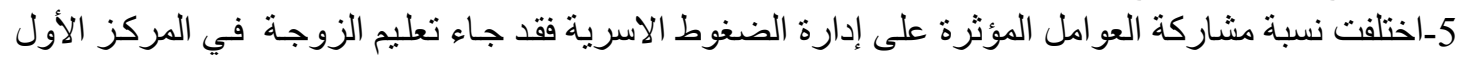

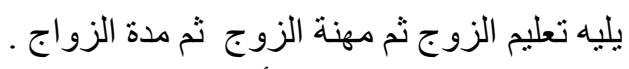

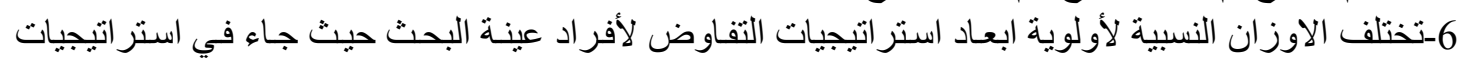

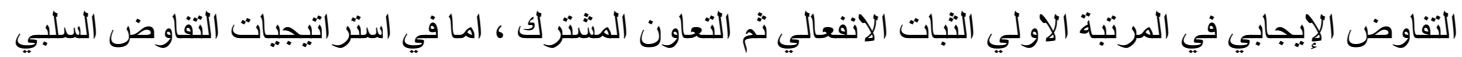

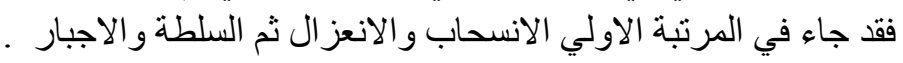

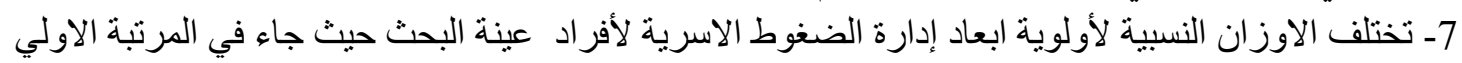

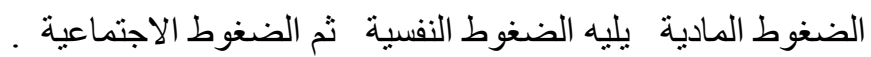

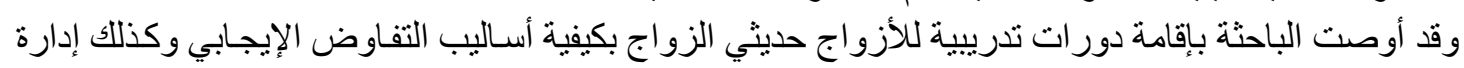
الضغوط الاسرية بشكل علمي. 


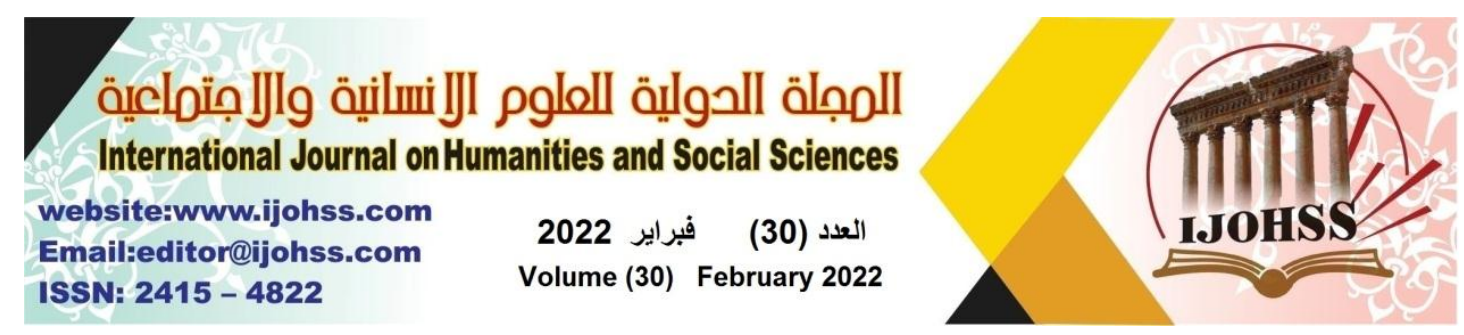

\title{
Negotiation Strategy between Spouses and its Reflection on Managing Family Pressures
}

\author{
Dr. Eman Shaban Ahmed \\ Professor in the Department of Housing and Home Management \\ College of Design and Arts - Umm Al-Qura University \\ Saudi Arabia
}

\begin{abstract}
The current research aims to study the relationship between negotiating strategies between spouses and family pressures. The research used the descriptive analytical approach, and the research sample was a random sample of (274 wives) of different economic and social levels. The study tools included a general data form for the family, a questionnaire of negotiation strategies and a questionnaire on stress management. The family was prepared by the researcher, and the most important results of the study were: 1 - There are statistically significant differences between the members of the research sample in the negotiation strategies between spouses with the study variables (the education of the spouses - the husband's profession - the wife's work - the duration of the marriage - the number of family members - the family's monthly income).

2 - There are statistically significant differences between the members of the research sample in managing family stress with the study variables (the education of the spouses the profession of the husband - the work of the wife - the duration of the marriage - the number of family members - the monthly income of the family).

3 - The existence of a correlational relationship between the axes of negotiation strategies and the axes of family pressures.

4- The percentage of participation of factors affecting negotiation strategies varied, as the husband's education came in the first place, followed by the period of marriage, then the husband's profession, and then the wife's education.

5- The percentage of participation of the factors affecting the management of family pressures varied. The education of the wife came in the first place, followed by the education of the husband, then the profession of the husband, then the duration of the marriage.

6-The relative weights of the priority dimensions of the negotiation strategies differ for the individuals of the research sample, where the positive negotiation strategies came in the first place, emotional stability, then joint cooperation, but in the negative negotiation strategies, withdrawal and isolation came in the first place, then power and coercion.

7- The relative weights of the priority dimensions of family stress management differ for the members of the research sample, where physical stress came first, followed by psychological stress, and then social stress.

The researcher recommended: holding training courses for newly married couples on how to methods of positive negotiation, as well as scientifically managing family pressures.
\end{abstract}

Keywords: negotiation strategy, family pressure. 
العدد (30) فيراير 2022

ISSN: $2415-4822$

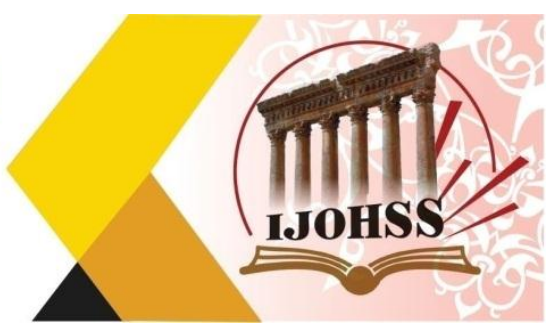

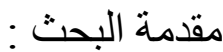

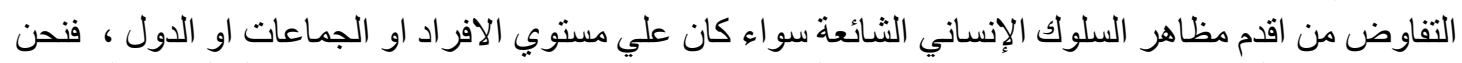

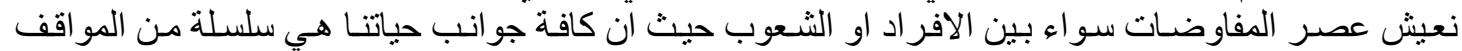

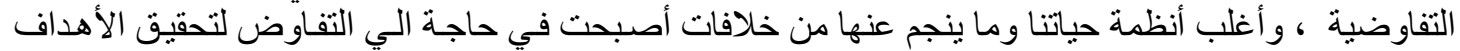
المشتركة (هند محمد ، (2020)

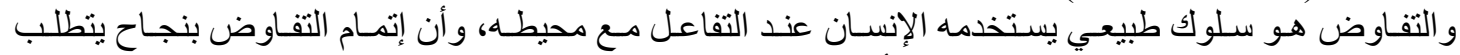

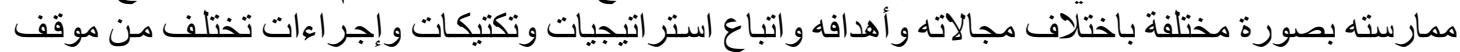

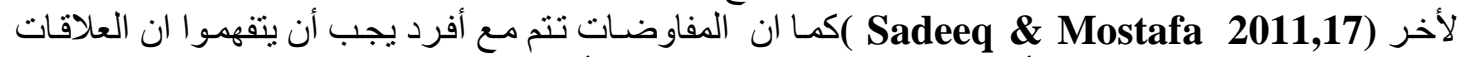

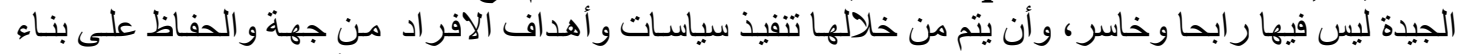

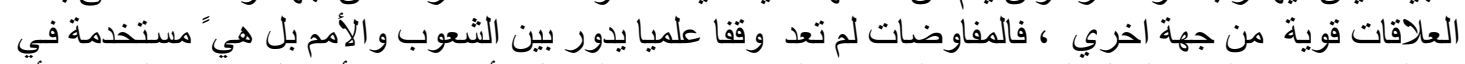

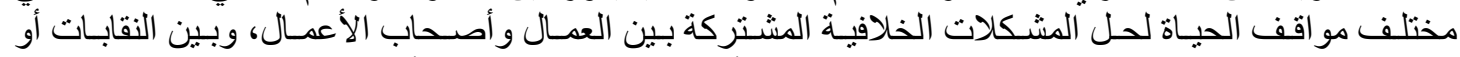

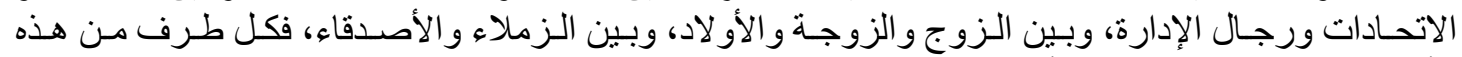

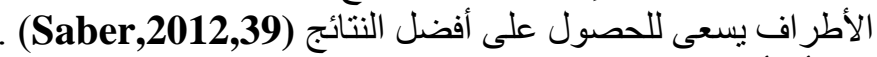

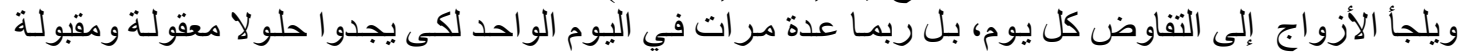

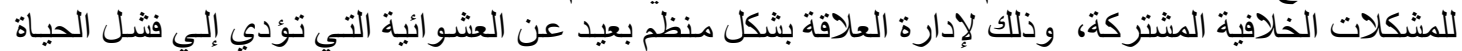

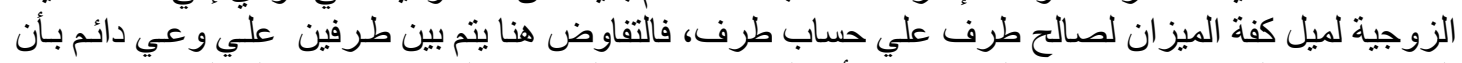

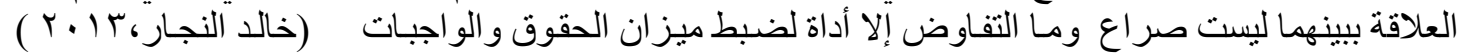

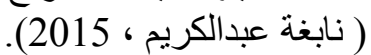

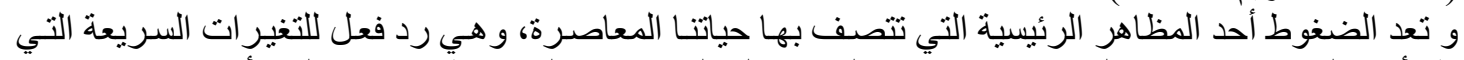

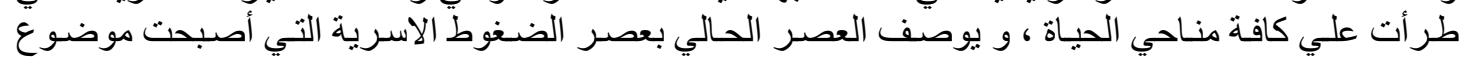

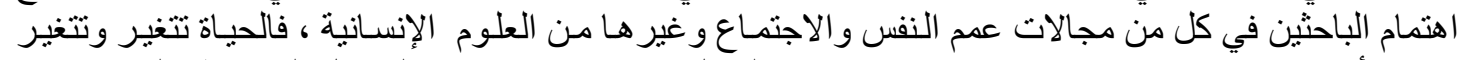

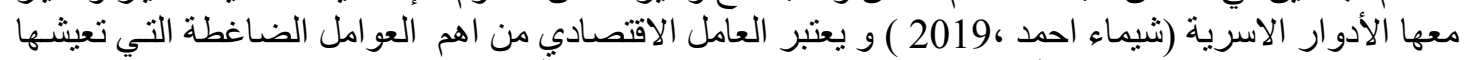

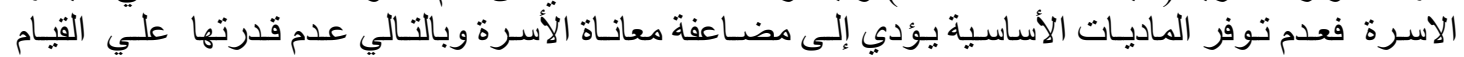

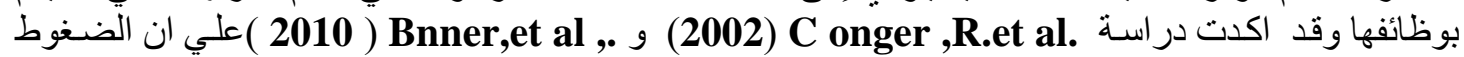

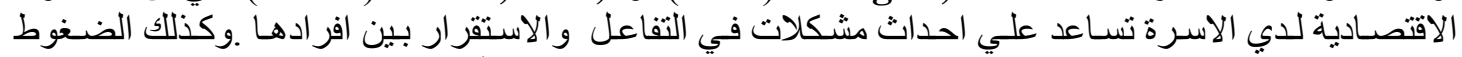

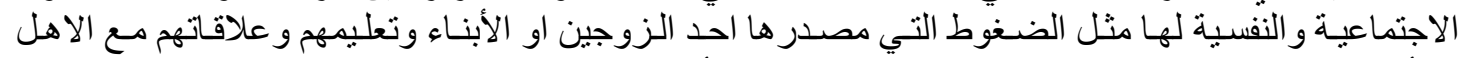

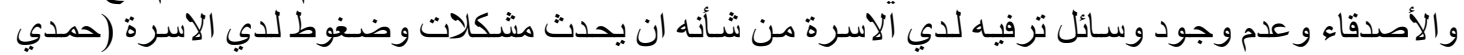

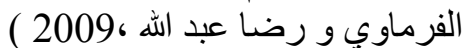

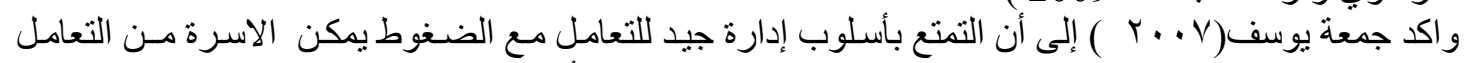

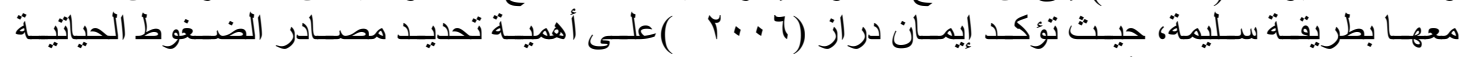

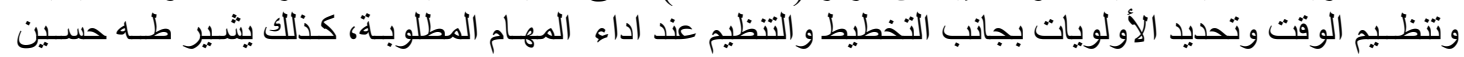

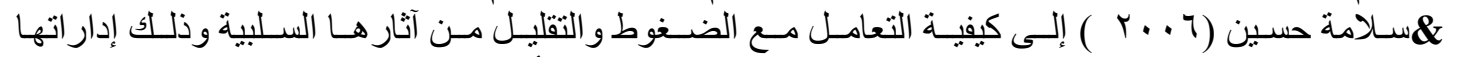

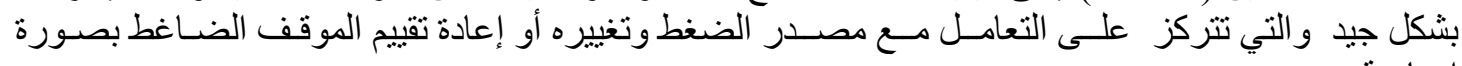
إيجابيـة مشكلة البحث: ائة

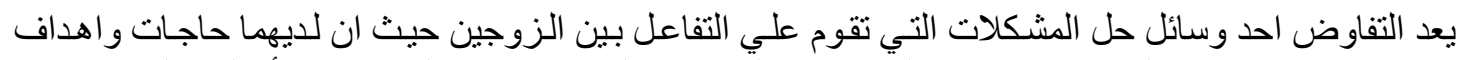

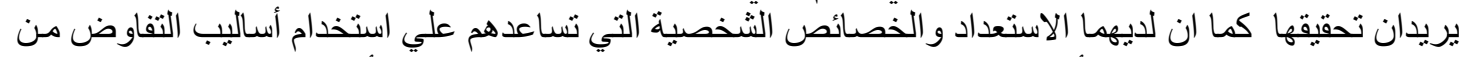

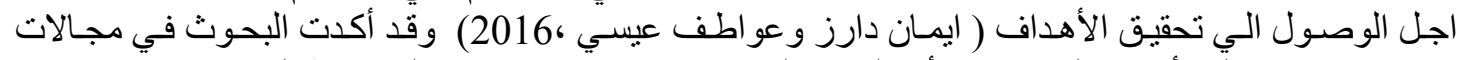

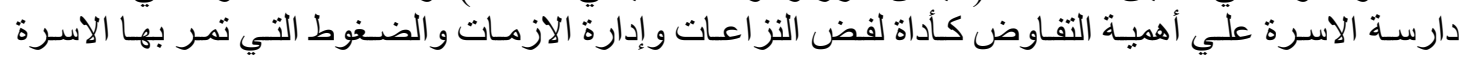

. ( Wasti\& Cortin ,2002 ) ، ( Radcliffe,2011)

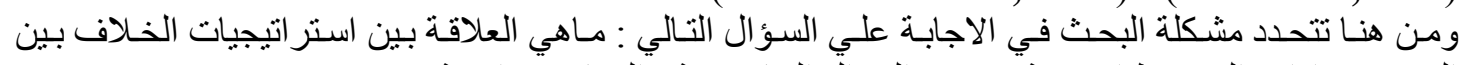
الزوجين و إدارة الضغوط الاسرية ؟ ومن السؤال السابق تنبثق التساؤلات الاتية: 


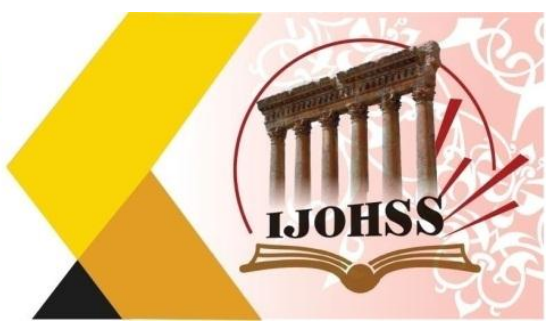

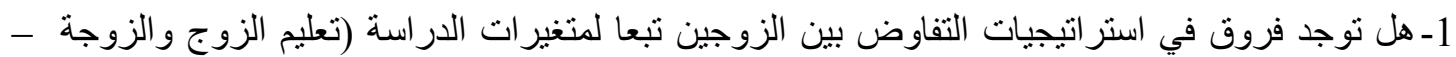

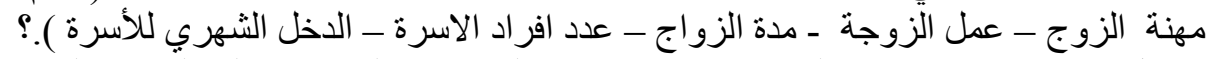

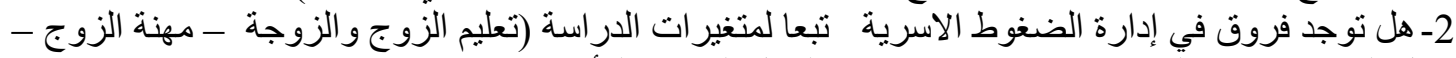

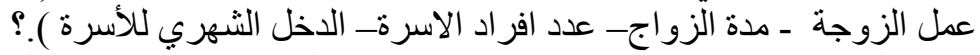

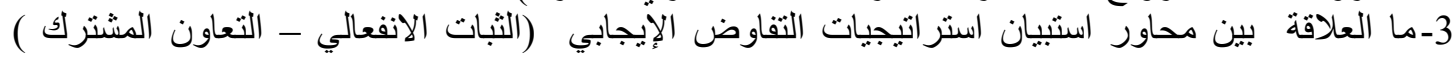

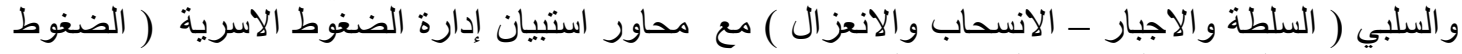

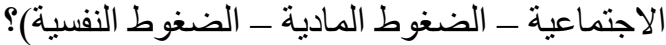

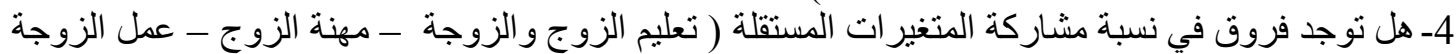

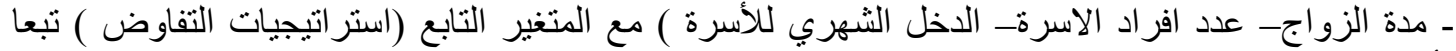

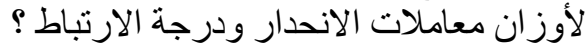

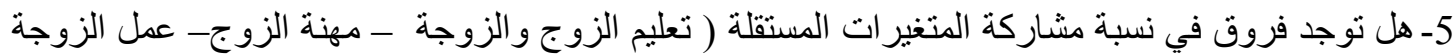

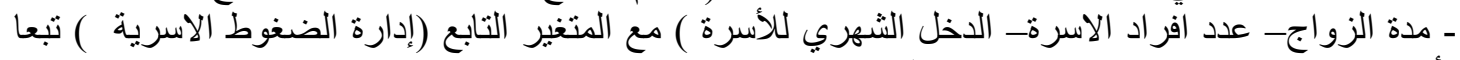

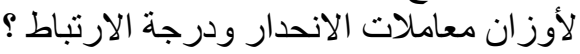

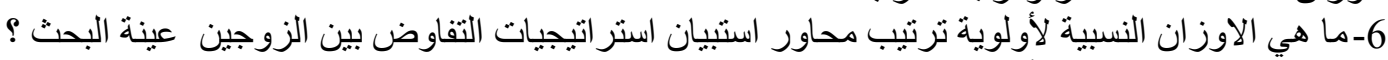

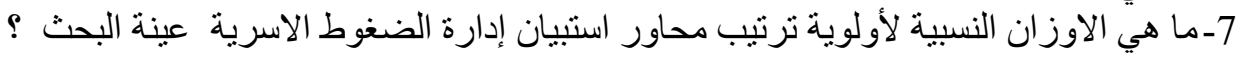

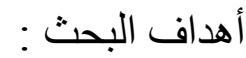
يهدف البحث الحالي الي الكثف عن تأثثير استراتيجيات التفاوض بين الزوجين و انعكاسه علي إدارة الضغوط

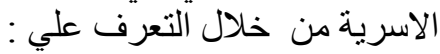

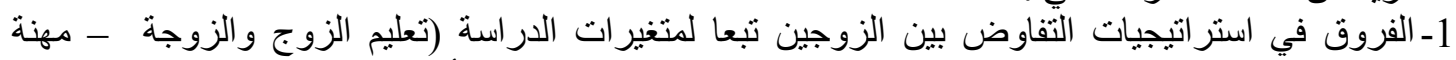

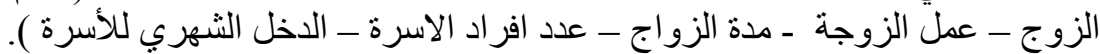

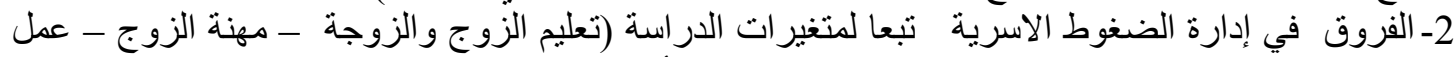

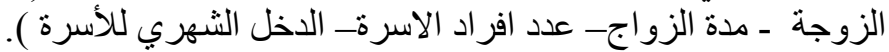

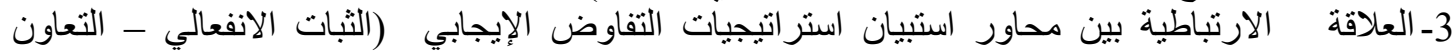

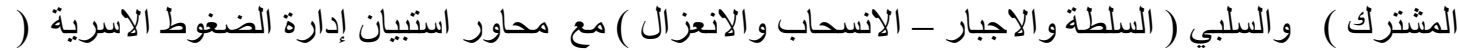

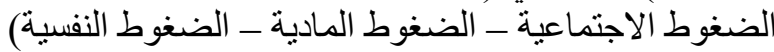

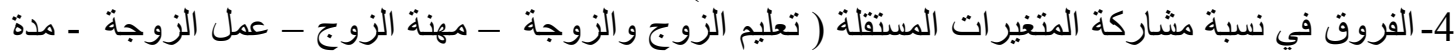

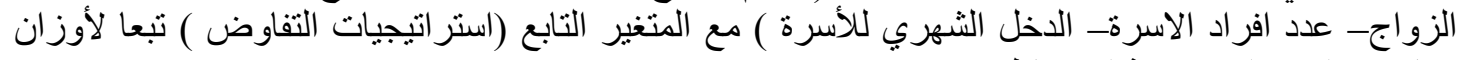

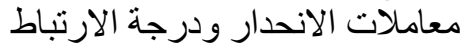

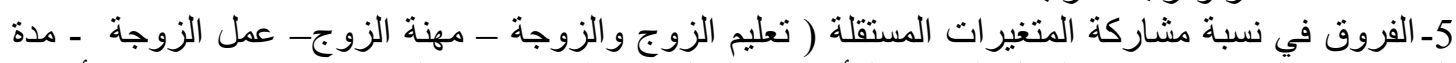

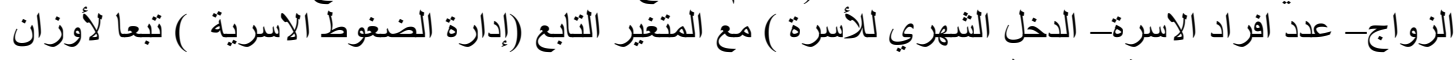

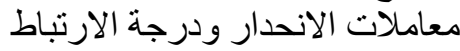

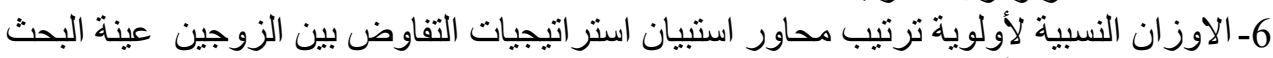

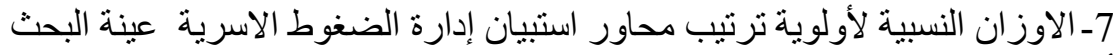

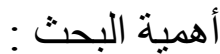

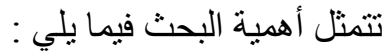

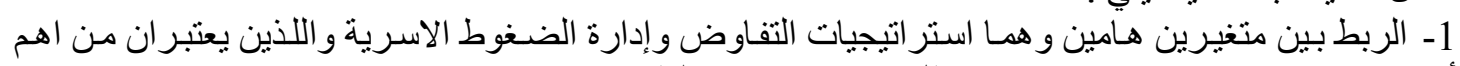

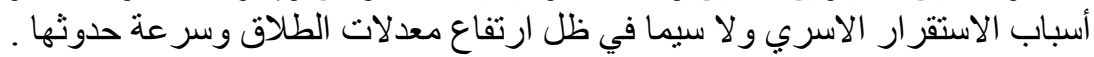

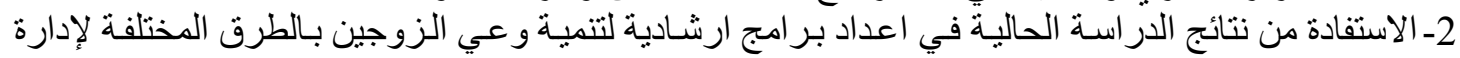

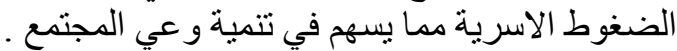

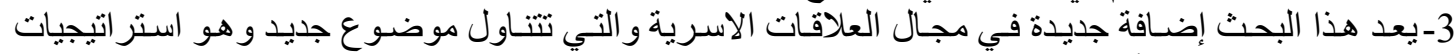
التفاوض بين الزوجين كأحد الموضو عات الهامة التي تساعد علي تحقيق حياة اسرية مستقرة . 


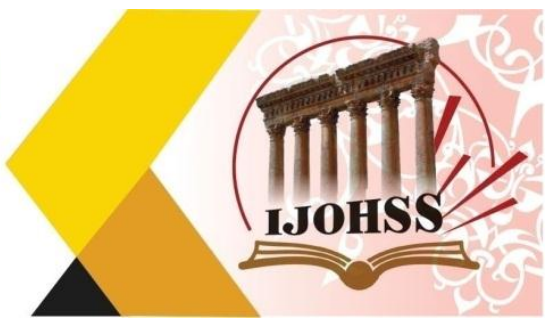

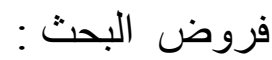

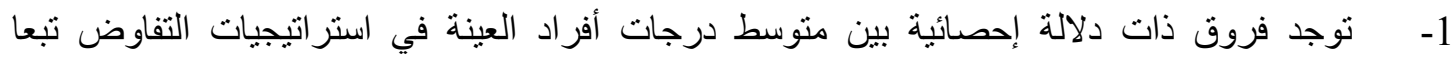

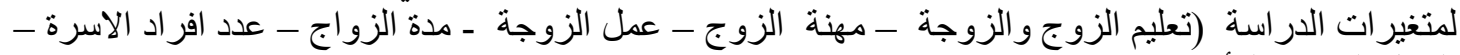

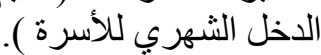

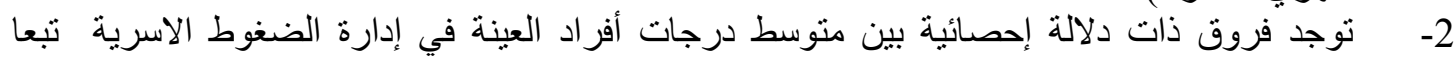

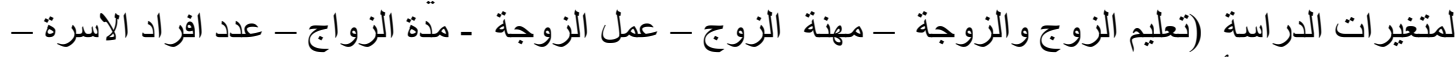

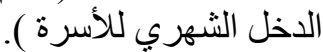
3- توجد علاقة ارنباطية بين محاور استبيان استراتيجيات التفاوض الإيجابي (الثبات الانفعالي - التعاون

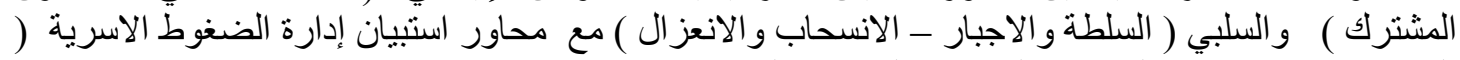

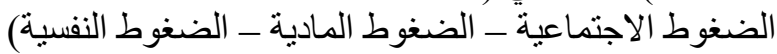

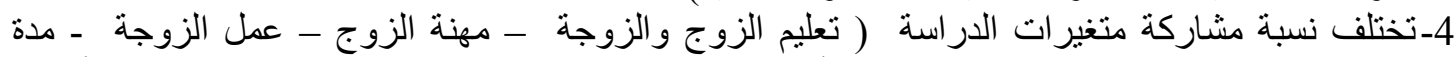

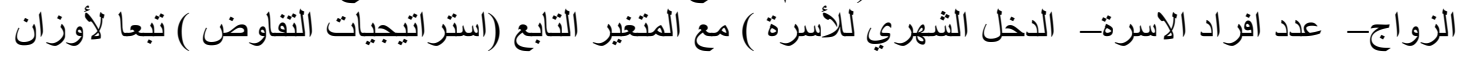

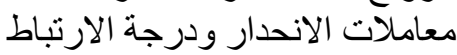

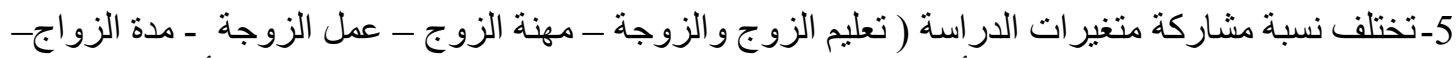

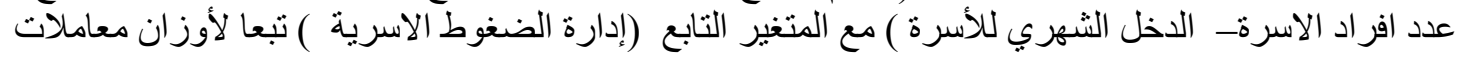

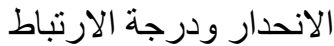

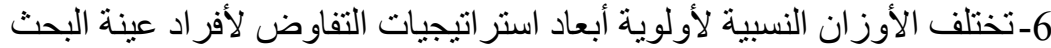
7ـ تختلف الأوزان النسبية لأولوية أبعاد إدارة الضغوط النية الاسرية لأفراد الاد عينة البحث

$$
\text { 1 } 1 \text { - الاسترات اتيجية : }
$$

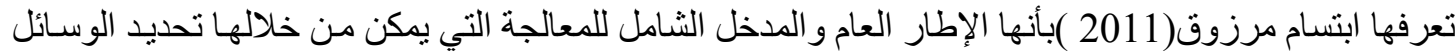
التي تعتمد في حسم المشاكل و المناز عات.

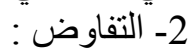

يعرفه نجيب نصر (2010) بأنه عملية اتصال بين شخصين أو أكثر يدرسون فيها البدائل للتوصل لحلول مقبولة

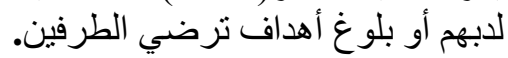

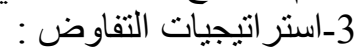

عرفها ثابت إدريس (2010 ) :انها الخطط التي يستخدمها المفاوض أثناء العملية التفاوضية كي تسـاعده علي

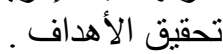

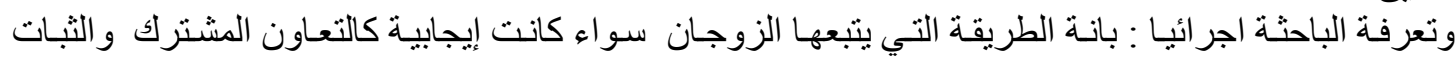

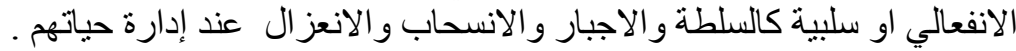

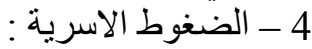

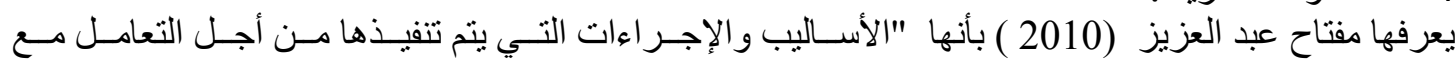

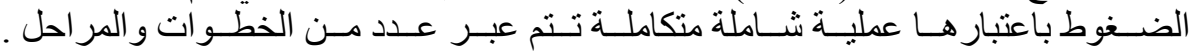

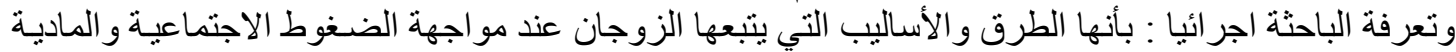

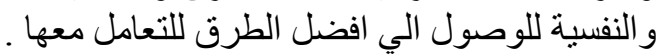

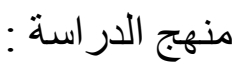

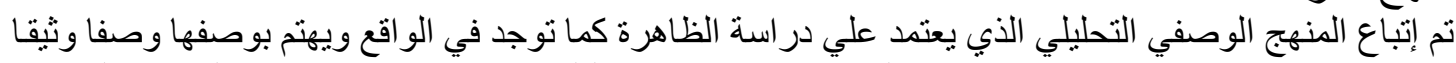

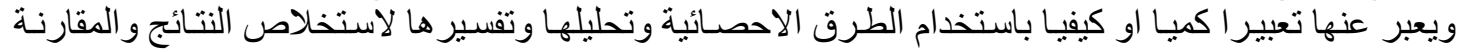

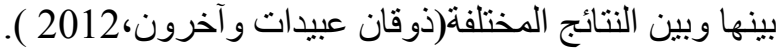
حدود الدر اسة : مانس

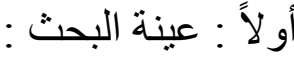

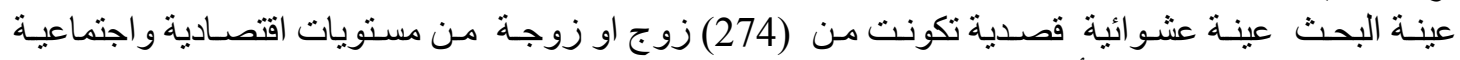
مختلفة وقد اشترط في العينة أن يتو اجد الزوجان معا في نفس المنزل 
العدد (30) فبراير 2022

Volume (30) February 2022

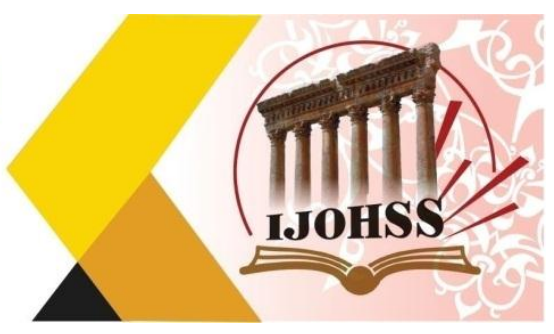

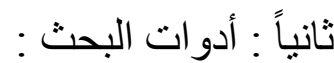
1 - استمارة البيانات العامة للأسرة .

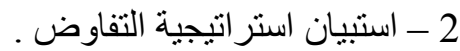
3 - استبيان إدارة الضغوط التئية الاسرية

1 - استمارة البيانات العامة للأسرة :
إعداد الباحثة.

إعداد الباحثة.

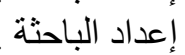

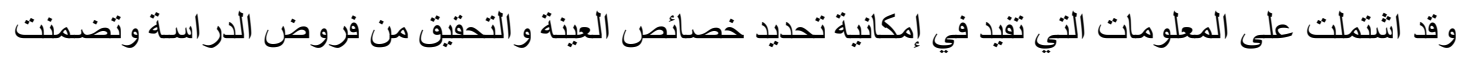

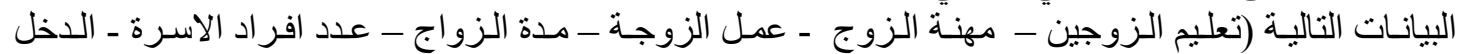

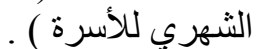

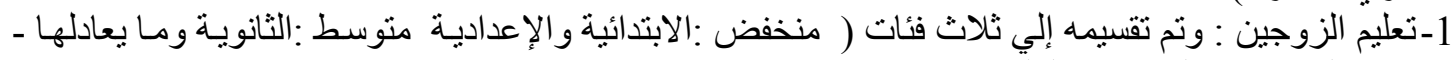

مرتفع : الجامعية و الدراسات العليا ).

2- عمر الزوجين :وتم تقنسيمها إلي ثلاث فئات ( أقل من 30 سنة ـ من 30 ألي أقل من 50 سنة - من 50 سنة

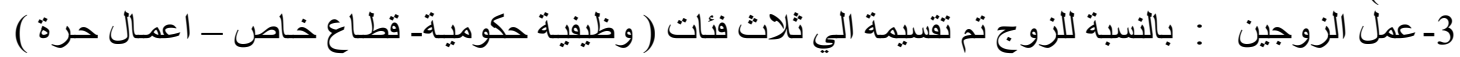
و الزوجة تقسيمه إلي فيتتين( تعمل - لا تعمل).

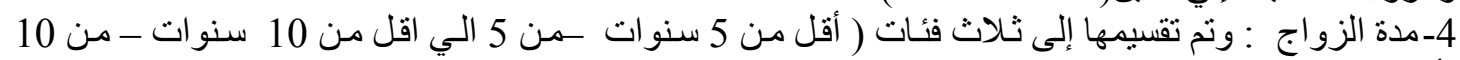
فأكثر ).

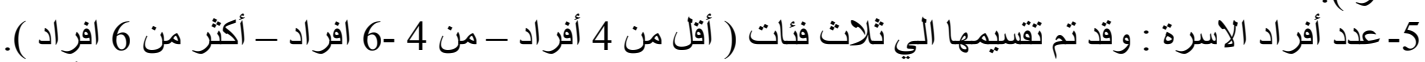

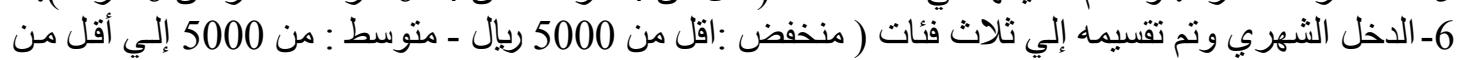

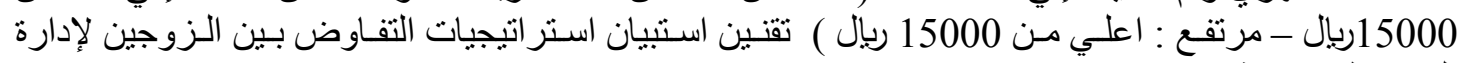

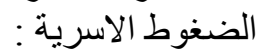
2 - استبيان إدارة التفاوض بين الزوجين :

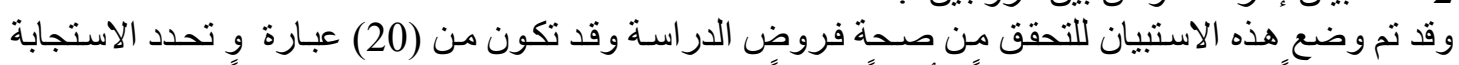

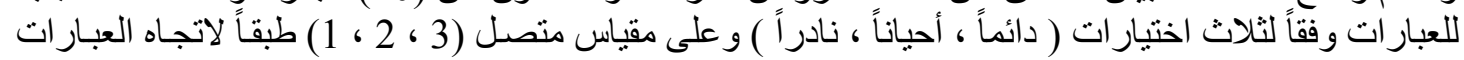

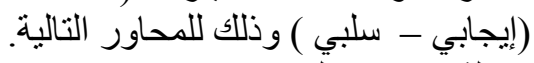

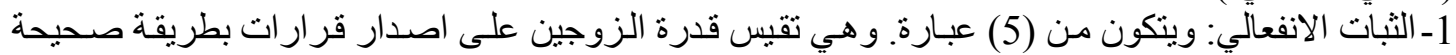

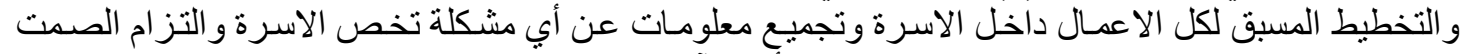

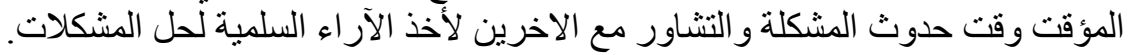

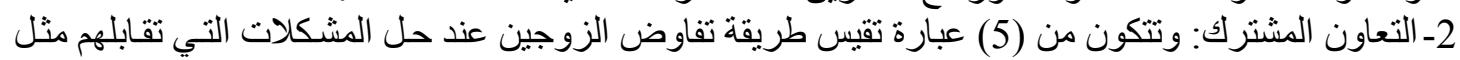

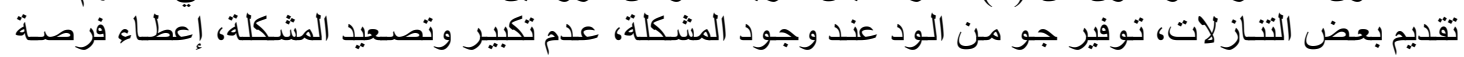

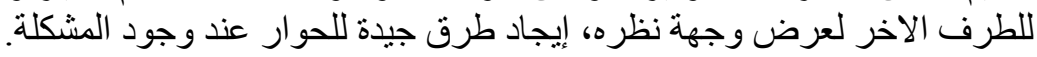

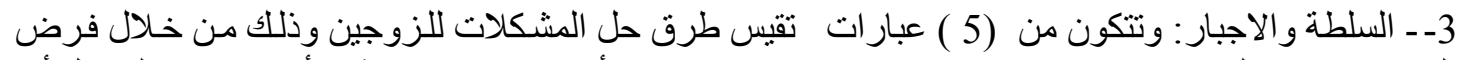

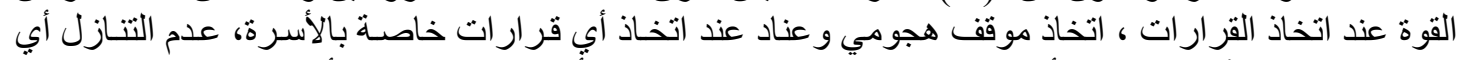

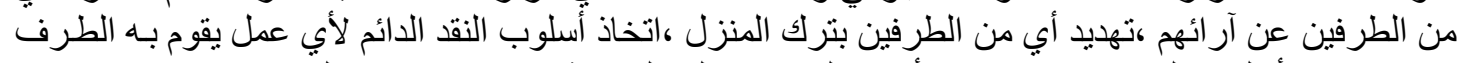

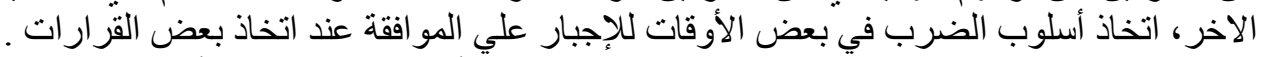

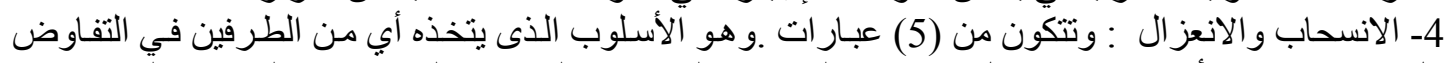

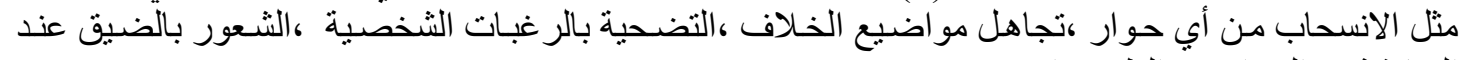

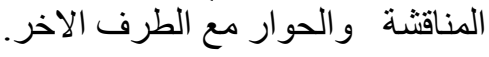

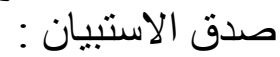

الصدق باستخدام الاتساق الداخلي بين الدرجة الكلية لكل محور و الدرجة الكلية للاستبيان ـ تم حساب الصدق الأبان

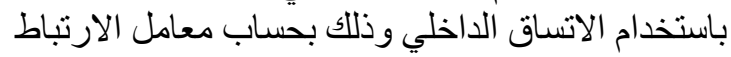

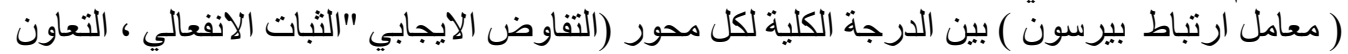

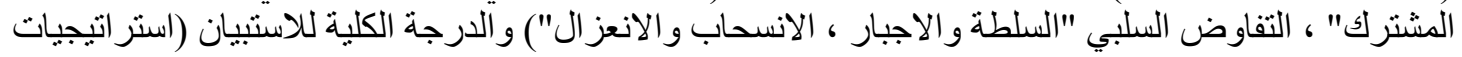
التفاوض) ، و الجدول التالي يوضح ذلي للك : 


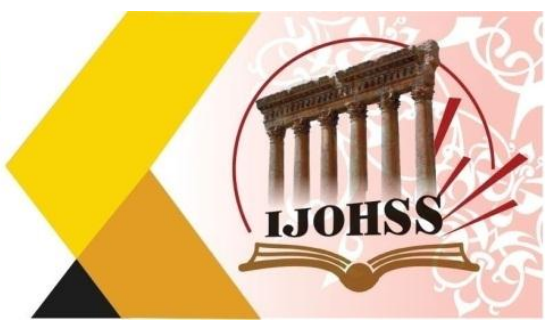

جدول ( 1 ) ميم معاملات الارتباط بين الدرجة الكلية

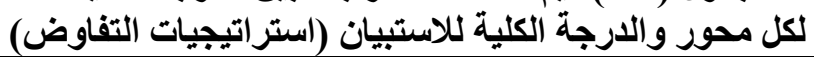

\begin{tabular}{|c|c|c|}
\hline 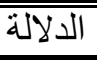 & الارتباط & محاور استر اتيجية التفاوض \\
\hline 0.01 & 0.806 & المحور الأول : التفاوض الايجابي \\
\hline 0.01 & 0.741 & المحور الأول الفرعي : الثبات الانفعالي \\
\hline 0.01 & 0.867 & المحور الثاني الفرعي : التعاون المشتركَ \\
\hline 0.01 & 0.775 & المحور الثاني : التفاوض السلبي \\
\hline 0.01 & 0.914 & المحور الأول الفرعي : السلطة والاجبار \\
\hline 0.01 & 0.882 & المحور الثاني الفرعي : الانسحاب و الانعز ال \\
\hline
\end{tabular}

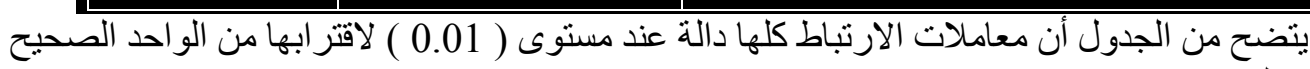

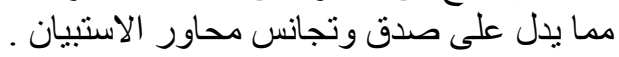

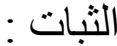

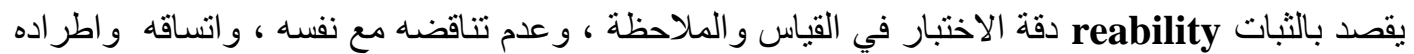

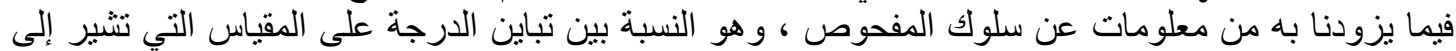

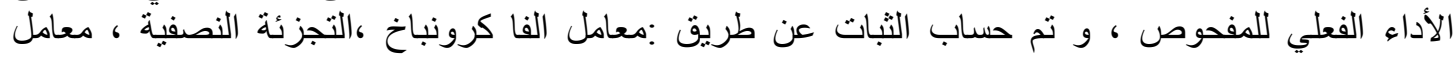
جدول (2) قيم معامل الثبات لمحاور استبيان استر اتيجيات التفاوض

\begin{tabular}{|c|c|c|c|c|}
\hline جيوتمان إن & سبراون & النصفئة & 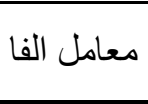 & المحاور \\
\hline 0.810 & 0.861 & 0.791 & 0.827 & المحور الأول : التفاوض الايجابي \\
\hline 0.892 & 0.945 & 0.872 & 0.906 & المحور الأول الفرعي : الثبات الانفعالي \\
\hline 0.785 & 0.839 & 0.763 & 0.791 & المحور الثاني الفرعي : التعاون المشتركَ \\
\hline 0.751 & 0.805 & 0.738 & 0.762 & المحور الثاني : التفاوض السلبي \\
\hline 0.822 & 0.871 & 0.804 & 0.830 & المحور الأول الفرعي : السلطة والاجبار \\
\hline 0.916 & 0.964 & 0.891 & 0.925 & المحور الثاني الفرعي : الانسحاب والانعز ال \\
\hline 0.842 & 0.892 & 0.825 & 0.851 & ثبات استبيان استر اتيجيات التفاوض ككل \\
\hline
\end{tabular}

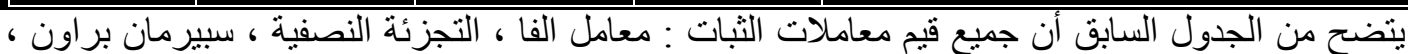
جيوتمان دالة عند مسنوى 0.01 مما يدل الدئ على ثبات الاستبيان

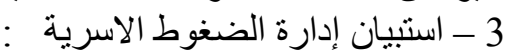

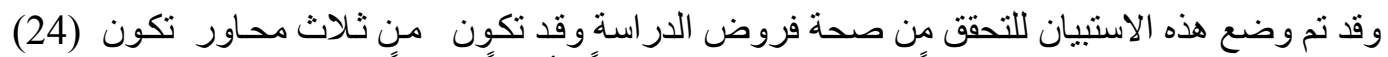

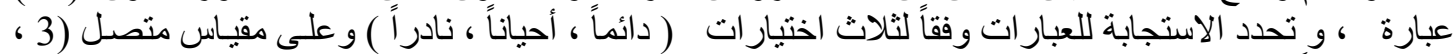

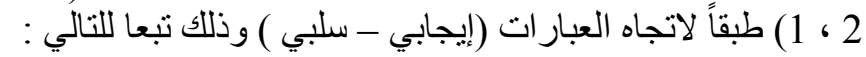

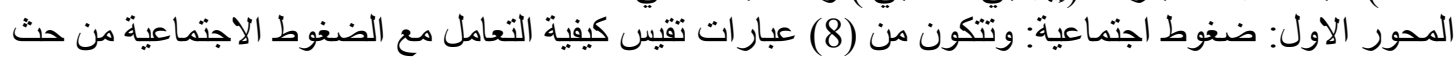

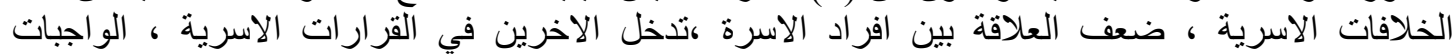

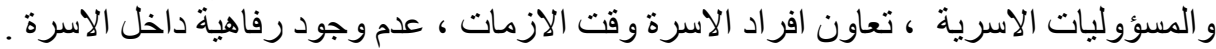

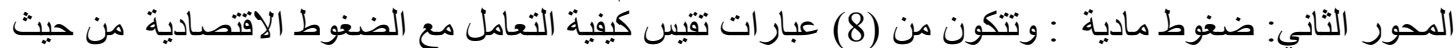

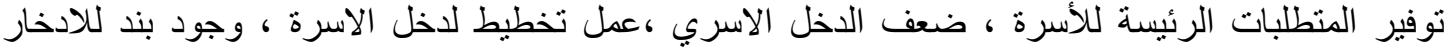

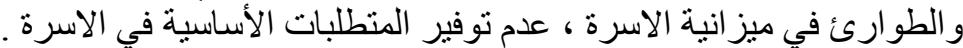

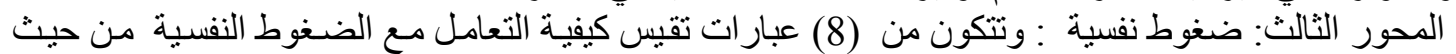

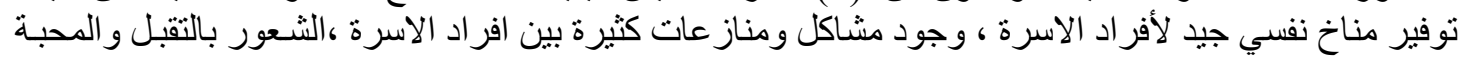

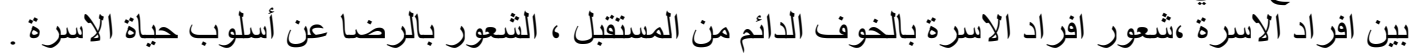




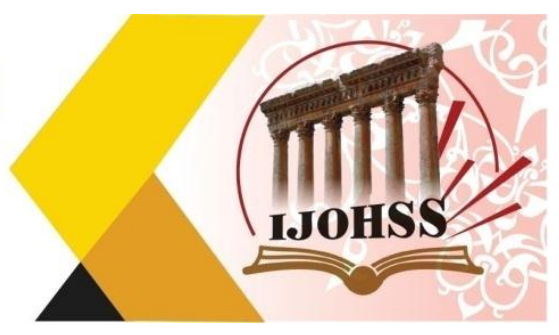

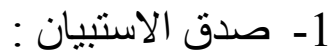

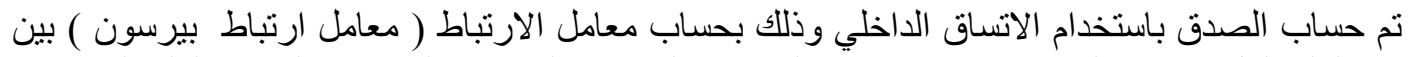
الدرجة الكلية لكل محور (الضغوط الاجنماعية ، الضغوط المادية ، الضغوط الضوالنية النفية) و الدرجة الكلية للاستبيان

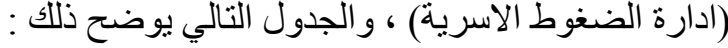
جدول ( 3 ) قيم معاملات الارتباط بين الدارجة الكلية لكل محور

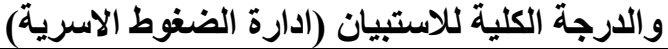

\begin{tabular}{|c|c|c|}
\hline 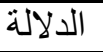 & الارتباط & محاور إدارة الضغوط الاسرية \\
\hline 0.01 & 0.937 & المحور الأول : الضغوط الاجتماعية \\
\hline 0.01 & 0.712 & الدحور الثاني : الضغوط المادية \\
\hline 0.01 & 0.836 & المحور الثالث : الضغوط النفسية \\
\hline
\end{tabular}

يتضح من الجدول أن معاملات الارتباط كلها دالة عند مستوى ( 0.01 ) لاقتز ابها من الو احد الصحيح مما يدل على صدق وتجانس محاور الاستبيان الثبات : بات

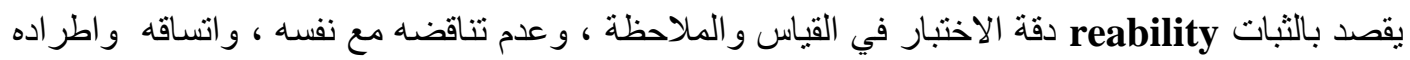

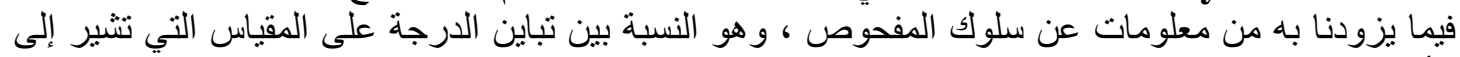

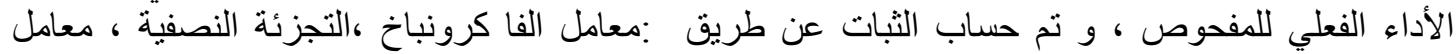
جدول ( 4 ) قيم معامل الثبات لمحاور استبيان ادارة الضغوط الاسرية

\begin{tabular}{|c|c|c|c|c|}
\hline 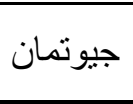 & سببيرمان & النصفية & 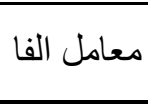 & 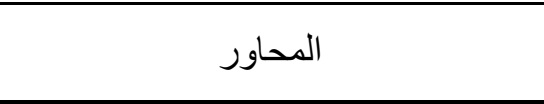 \\
\hline 0.904 & 0.958 & 0.888 & 0.916 & المحور الأول : الضغوط الاجتماعية \\
\hline 0.743 & 0.792 & 0.723 & 0.754 & المحور الثاني : الضغوط المادية \\
\hline 0.851 & 0.903 & 0.832 & 0.866 & المحور الثالث : الضغوط النفسية \\
\hline 0.792 & 0.841 & 0.774 & 0.807 & ثبات استبيان ادارة الضغوط الاسرية ككل \\
\hline
\end{tabular}

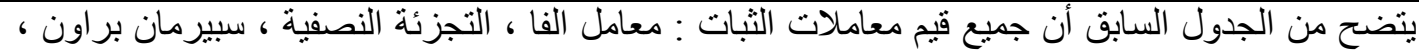

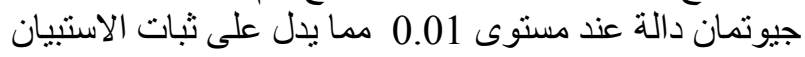

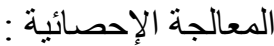

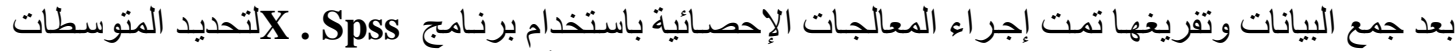

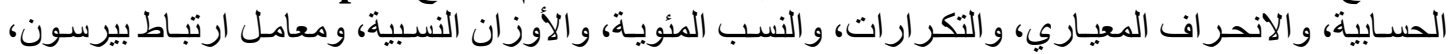

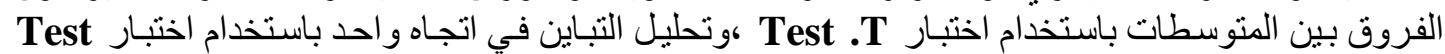

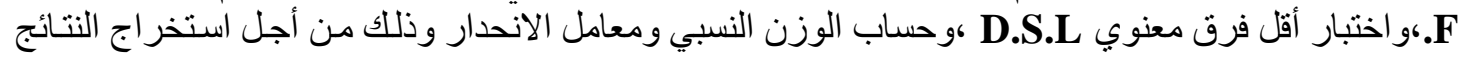
ومناقثتها

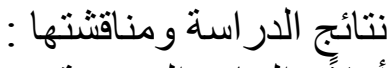
أولاً : النتائج الوصفية الوردية : 1

جدول ( 5 ) توزيع أفراد عينة البحث تبعاً لمتغير تعليم الزوج

\begin{tabular}{|c|c|c|}
\hline النسبة\%\% & العدد & تعليم الزوج \\
\hline$\% 24.4$ & 67 & منخفض \\
\hline$\% 32.5$ & 89 & متوسط \\
\hline$\% 43.1$ & 118 & عالي \\
\hline
\end{tabular}




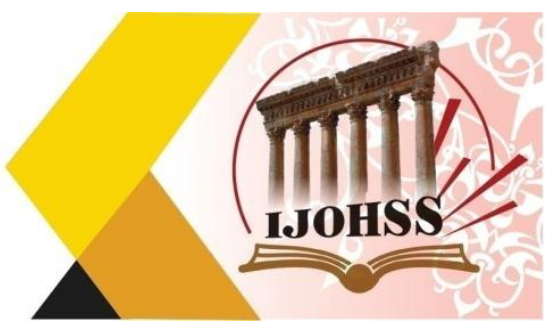

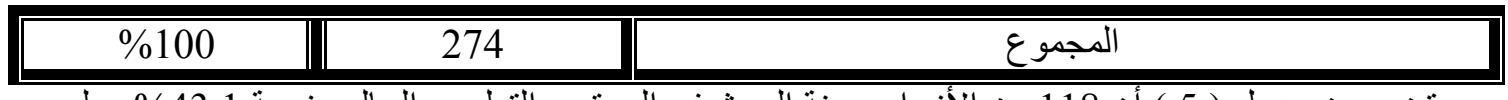

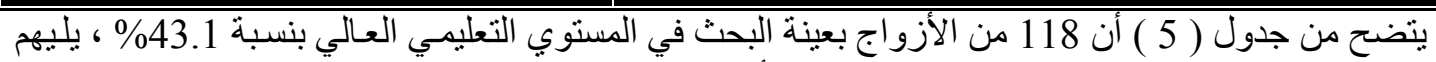
89 في المستوي التعليمي المنوسط بنسبة 32.5\% ، و وأخيرا 67 في المستوي التعليمي المنخفض بنسبة 24.4\%

جدول ( 6 ) توزيع أفراد عينة البحث تبعاً لمتغير تعليم الزوجة

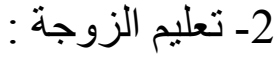

\begin{tabular}{|c|c|c|}
\hline النسبة\%\% & العدد & تعليم الزوجة \\
\hline$\% 27.7$ & 76 & منخفض \\
\hline$\% 31$ & 85 & منوسط \\
\hline$\% 41.2$ & 113 & عالي \\
\hline \%100 & 274 & المجموع \\
\hline
\end{tabular}

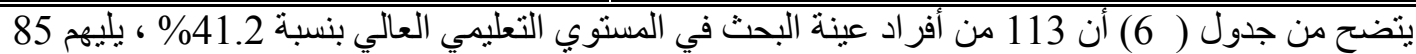

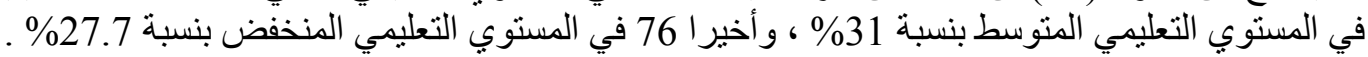
جدول ( 7 ) توزيع أفراد عينة البحث تبعاً لمتغير مهنة الزوج

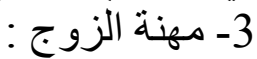

\begin{tabular}{|c|c|c|}
\hline النسبة\%\% & العدد & مهنة الزوج \\
\hline \%50.7 & 139 & وظيفة حكومية \\
\hline$\% 28.8$ & 79 & قطاع خاص \\
\hline$\% 20.4$ & 56 & أعمال حرة \\
\hline$\% 100$ & 274 & المجموع \\
\hline
\end{tabular}

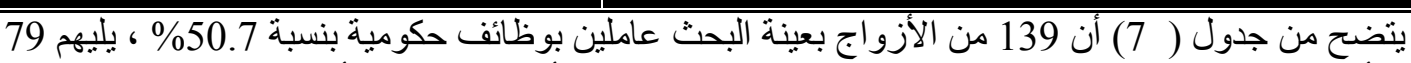
من الأزواج بعينة البحث عاملين بالقطاع الخاص بنسبة 28.8\% ، و وأخيرا 56 من الأزواج بعينة البحث عاملين

جدول (8 ) توزيع أفراد عينة البحث تبعا لمتغير العمل

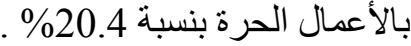

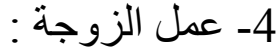

\begin{tabular}{|c|c|c|}
\hline النسبة\%\% & العدد & عمل الزوجة \\
\hline$\%$ \%57.7 & 158 & تعمل \\
\hline$\% 42.3$ & 116 & لا تعمل \\
\hline$\% 100$ & 274 & المجموع \\
\hline
\end{tabular}

يتضح من جدول ( 8) أن 158 من أفراد عينة البحث عاملات بنسبة 57.7\% ، بينما 116 من أفراد عينة

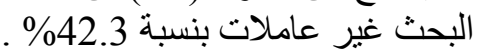

جدول (9 ) توزيع أفراد عينة البحث تبعا لمتغير مدة الزواج

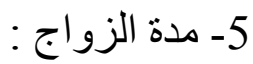

\begin{tabular}{|c|c|c|}
\hline النسبة\%\% & 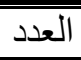 & مدة الزواج \\
\hline$\% 25.2$ & 69 & أقل من 5 سنوات \\
\hline$\% 42.7$ & 117 & من 5 سنو ات لأقل من 10 سنوات \\
\hline$\% 32.1$ & 88 & من 10 سنو ات فأكثر \\
\hline
\end{tabular}




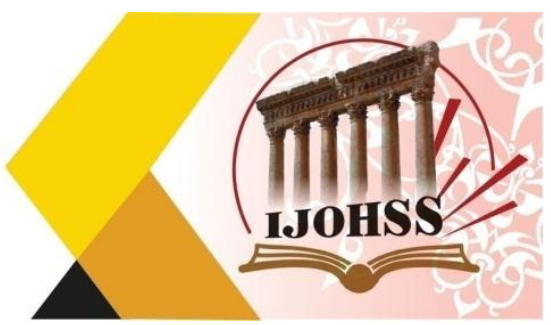

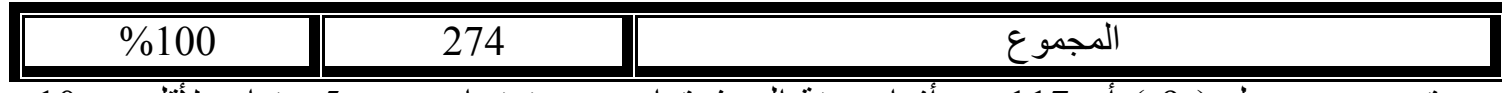

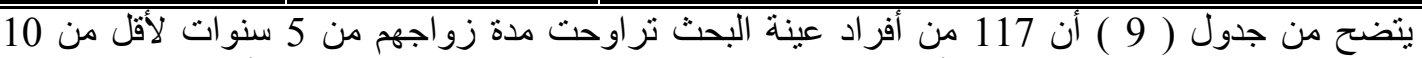

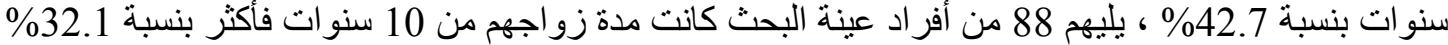

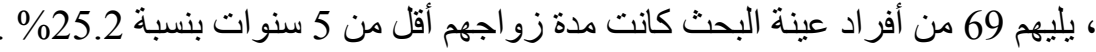

جدول ( 10 ) توزيع أسر عينة البحث تبعاً لعدد أفرادها

$$
\text { 6- - 2 - عدد أفر اد الأسرة : }
$$

\begin{tabular}{|c|c|c|}
\hline النسبة\%\% & العدد & عدد أفر اد الأسرة \\
\hline$\% 32.8$ & 90 & أقل من 4 أفر اد \\
\hline$\% 44.2$ & 121 & من 4 أفر اد لأقل من 6 أفراد \\
\hline$\% 22.9$ & 63 & من 6 أفر اد فأكثر \\
\hline$\% 100$ & 274 & المجموع \\
\hline
\end{tabular}

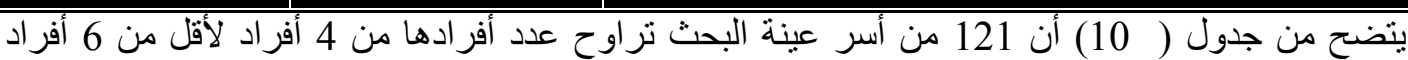

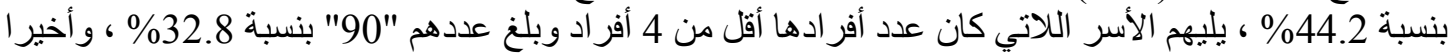

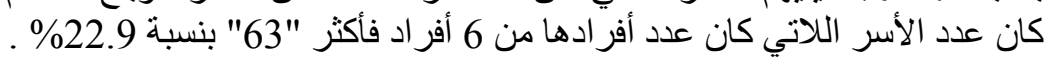

جدول (11) توزيع أسر عينة البحث وفقا لفئات الاخل المختلفة

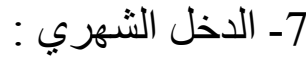

\begin{tabular}{|c|c|c|}
\hline النسبة\%\% & العدد & الدخل الشهري \\
\hline$\% 25.9$ & 71 & منخفض \\
\hline$\% 31.8$ & 87 & متوسط \\
\hline$\% 42.3$ & 116 & مرتفع \\
\hline \%\%100 & 274 & المجموع \\
\hline
\end{tabular}

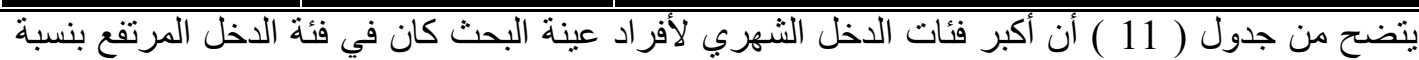

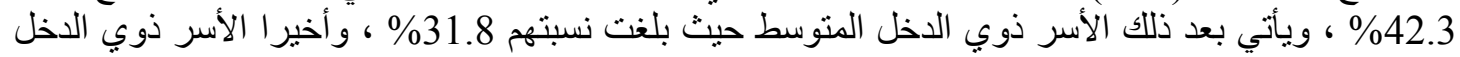

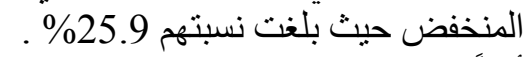

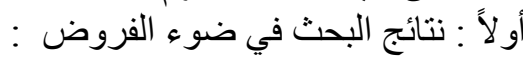

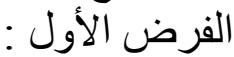

توجد فروق ذات دلالة إحصائية بين متوسط درجات أفر اد العينة في استراتيجيات التفاوض تبعا لمتغيرات الدر اسة - اسة

جدول ( 12) تحليل التباين لارجات أفراد العينة في استراتيجيات التفاوض تبعا لمتغيرات الاراسة

\begin{tabular}{|c|c|c|c|c|c|}
\hline الدلالة & قيمة (ف) & درجات الحرية & متوسط المربعات & مجموع المربعات & تعليم الزوج \\
\hline \multirow{2}{*}{0.01 دال } & \multirow{2}{*}{57.877} & 2 & 7731.349 & 15462.698 & بين المجمو عات \\
\hline & & 271 & 133.583 & 36201.082 & داخل المجمو عات \\
\hline & & 273 & & 51663.780 & المجموع \\
\hline الدلالة & قيمة (ف) & درجات الحرية & متوسط المربعات & مجموع المربعات & تعليم الزوجة \\
\hline \multirow{2}{*}{0.01 دال } & \multirow{2}{*}{44.655} & 2 & 7531.628 & 15063.256 & بين المجمو عات \\
\hline & & 271 & 168.661 & 45707.205 & داخل المجمو عات \\
\hline
\end{tabular}


website:www.ijohss.com

Email:editor@ijohss.com

ISSN: $2415-4822$
العدد (30) فبراير 2022

Volume (30) February 2022

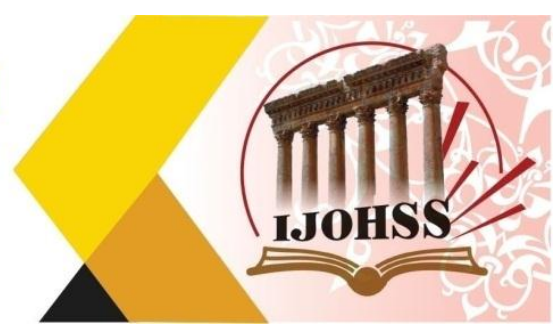

\begin{tabular}{|c|c|c|c|c|c|}
\hline & & 273 & & 60770.461 & المجموع \\
\hline الدلالة & قيمة (ف) & درجات الحرية & متوسط المربعات & مجموع المربعات & مهنة الزوج \\
\hline \multirow{3}{*}{0.01 دال } & \multirow{2}{*}{33.451} & 2 & 6937.290 & 13874.581 & بين المجموعات \\
\hline & & 271 & 207.387 & 56201.841 & داخل المجمو عات \\
\hline & & 273 & & 70076.422 & المجموع \\
\hline الدلالة & قيمة (ف) & درجات الحرية & متوسط المربعات & مجموع المربعات & مدة الزواج \\
\hline \multirow{3}{*}{0.01 دال } & \multirow{2}{*}{65.806} & 2 & 7508.623 & 15017.246 & بين المجمو عات \\
\hline & & 271 & 114.102 & 30921.737 & داخل المجمو عات \\
\hline & & 273 & & 45938.983 & المجموع \\
\hline الدلالة & قيمة (ف) & درجات الحرية & متوسط المربعات & مجموع المربعات & عدد أفر اد الأسرة \\
\hline \multirow{2}{*}{0.01 دال } & \multirow{2}{*}{36.953} & 2 & 7067.303 & 14134.605 & بين المجمو عات \\
\hline & & 271 & 191.251 & 51829.052 & داخل المجمو عات \\
\hline & & 273 & & 65963.657 & المجموع \\
\hline الدلالة & قيمة (ف) & درجات الحرية & متوسط المربعات & مجموع المربعات & الاخل الشهري \\
\hline \multirow{3}{*}{0.01 دال } & \multirow{2}{*}{51.364} & 2 & 7326.508 & 14653.016 & بين المجمو عات \\
\hline & & 271 & 142.639 & 38655.063 & داخل المجمو عات \\
\hline & & 273 & & 53308.079 & المجموع \\
\hline
\end{tabular}

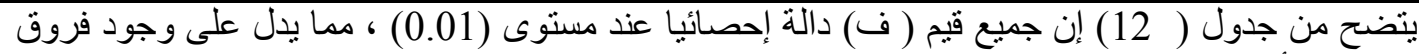

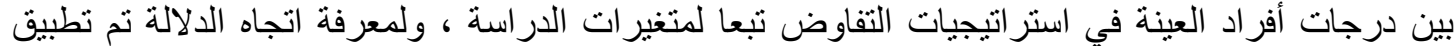

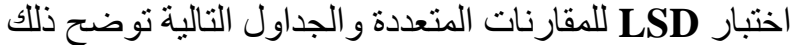
جدول ( 13 13) اختبار LSD للمقارنات المتعددة

\begin{tabular}{|c|c|c|c|}
\hline م = عالي & م = = منوسط & م = منخفض & تعليم الزوج \\
\hline & & - & منخفض \\
\hline & - & $* * 8.411$ & متوسط \\
\hline- & $* * 14.604$ & $* * 23.015$ & عالي \\
\hline
\end{tabular}

يتضح من جدول ( 13 ) وجود فروق في استر اتيجيات التفاوض بين الأزواج في المستوى التعليمي العالي التي

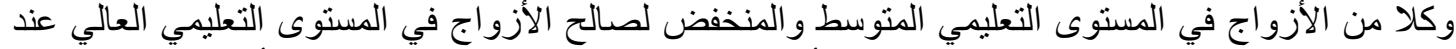

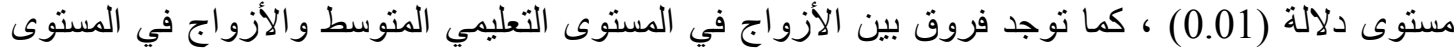

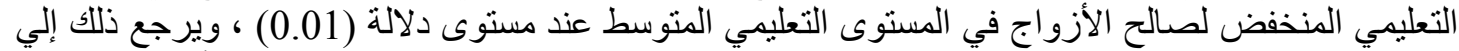

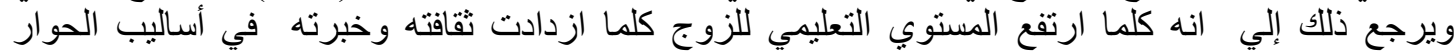

جدول ( 14 ) اختبار LSD للمقارنات المتعددة و التفاوض مع الزوجة ذئ الئ

\begin{tabular}{|c|c|c|c|}
\hline م = عالي = 53.291. & م = متوسط & من = منفضض & تعليم الزوجة \\
\hline & & - & منخفض \\
\hline & - & $* * 9.054$ & متوسط \\
\hline
\end{tabular}




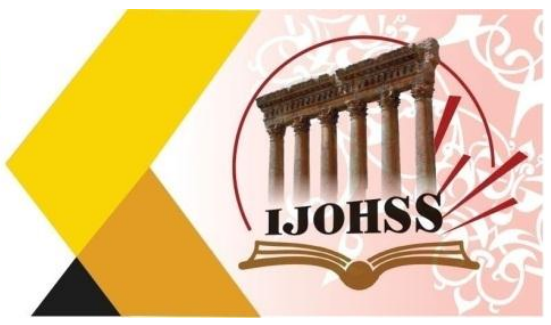

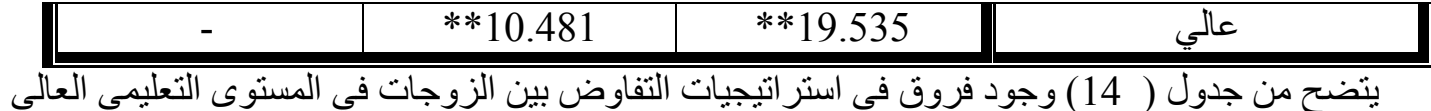

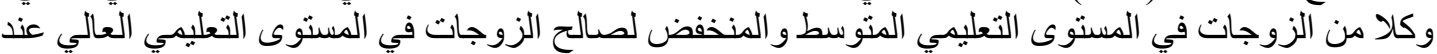

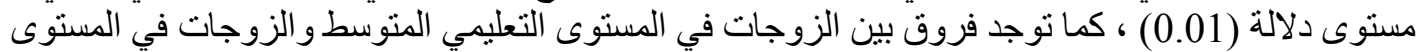

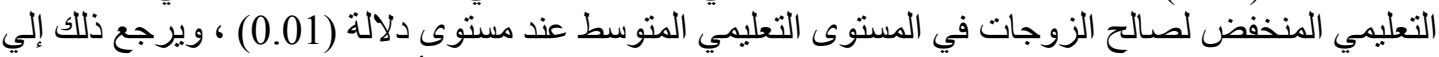

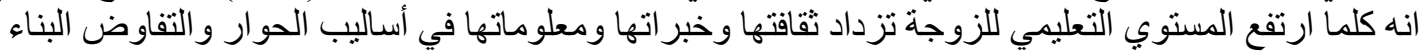

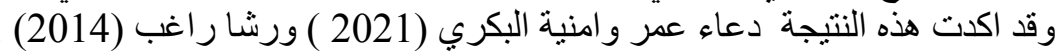
جذول ( 15 ) اختبار LSD للمقارنات المتعددة (202 )

\begin{tabular}{|c|c|c|c|}
\hline م = أعمال حرة & ق =طاع خاص 20.580 & وظيفة حكومية & مهنة الزوج \\
\hline & & - & وظيفة حكو مية \\
\hline & - & $* * 8.876$ & قطاع خاص \\
\hline- & $* 2.559$ & $* * 11.435$ & أعمال حرة \\
\hline
\end{tabular}

يتضح من جدول ( 15) وجود فروق في استر اتيجيات التفاوض بين الأزواج العاملين بالوظائف الحكومية وكلا

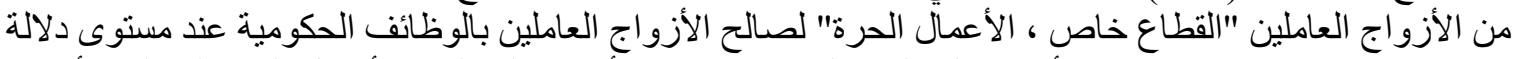
(0.01) ، بينما توجد فروق بين الأزواج العاملين بالقطاع خاص والأزئ الأزواج العاملين بالأعمال الحرة لصالحالح الأزواج

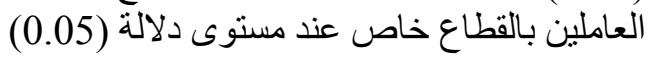

جدول ( 16) اختبار LSD للمقارنات المتعددة

\begin{tabular}{|c|c|c|c|}
\hline من 10 سنو 10 منر & من 5 سنوات سنوات 10 من & من = أقل من 5 من & 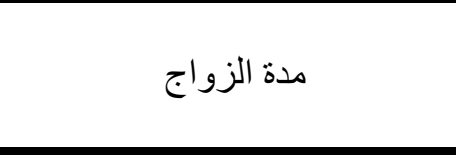 \\
\hline & & - & أقلّ من 5 سنو ات \\
\hline & - & $* * 10.877$ & من 5 سنو ات لأقل من 10 سنو ات \\
\hline - & $* * 15.595$ & $* * 26.472$ & من 10 سنو ات فأكثر \\
\hline
\end{tabular}

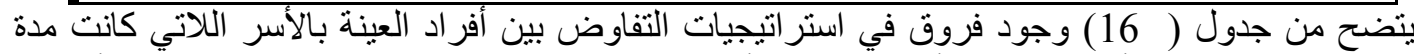

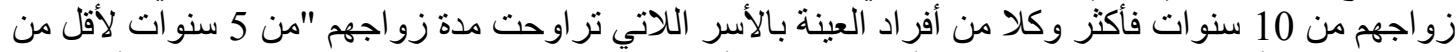

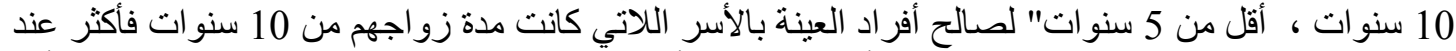

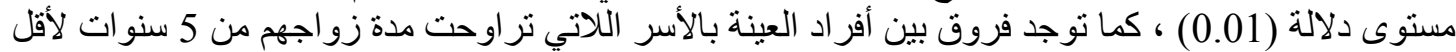

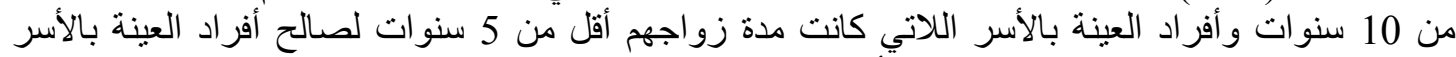

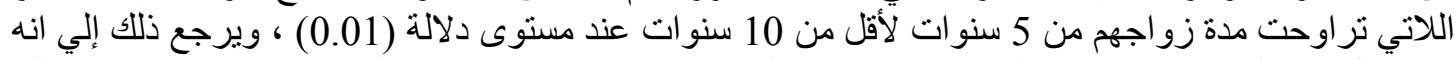

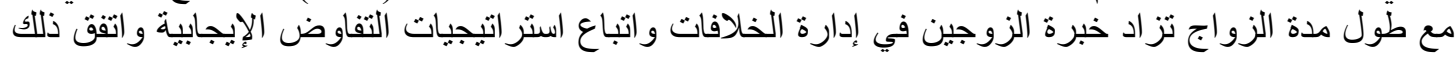

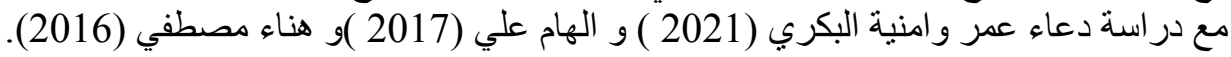
جدول ( 17) اختبار LSD للمقارنات المتعددة

\begin{tabular}{|c|c|c|c|}
\hline من 6 أفر اد فأكثر 38.527 من & من 4 أفر اد لأقل 6 من أفر اد & أقل = من 4 أفر اد 52.281 & عدد أفر اد الأسرة \\
\hline & & - & أقل من 4 أفر اد \\
\hline & - & $* * 11.418$ & من 4 أفر اد لأقلَ من 6 أفر اد \\
\hline- & *2.336 & $* * 13.754$ & من 6 أفر اد فأكثر \\
\hline
\end{tabular}




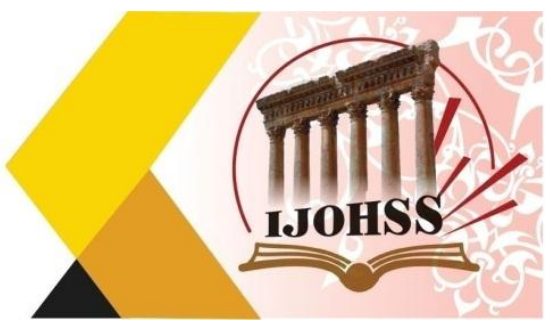

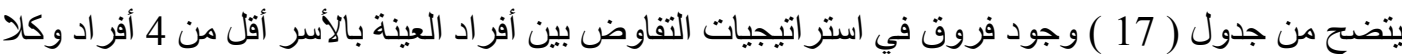

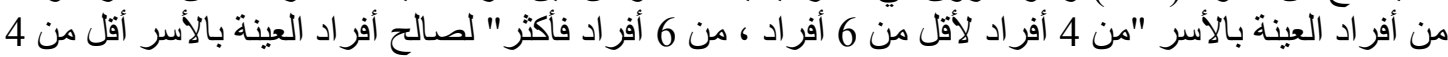

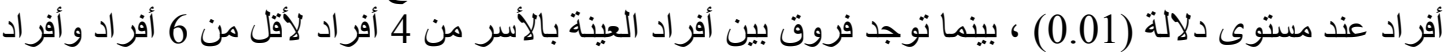

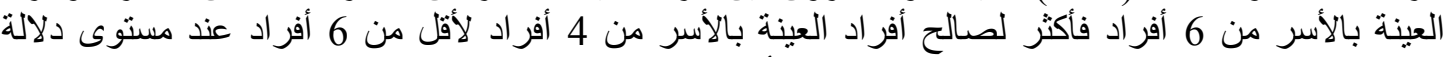

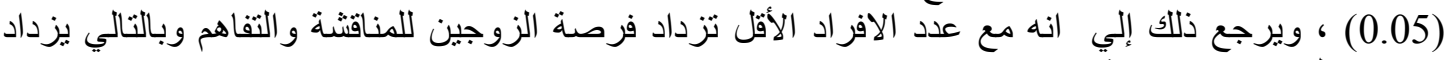
جدول ( 18 ) اختبار LSD للمقارنات المتعددة

\begin{tabular}{|c|c|c|c|}
\hline م = مرتفع 55.055 & م = متوسط & م = منخفض 32.123 & الدخل الثهري \\
\hline & & - & منخفض \\
\hline & - & $* * 11.247$ & متوسط \\
\hline - & $* * 11.685$ & $* * 22.932$ & مرتفع \\
\hline
\end{tabular}

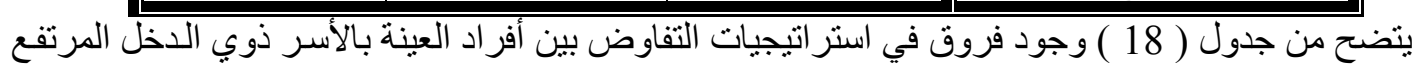

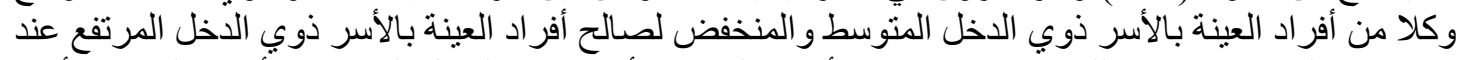

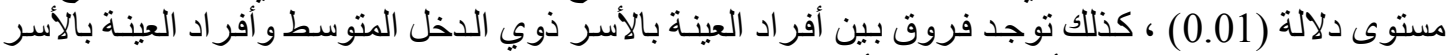

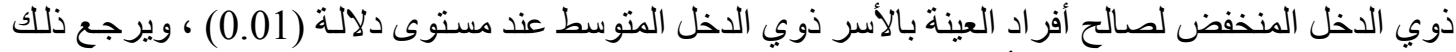

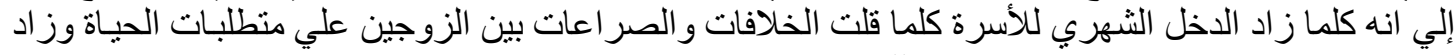

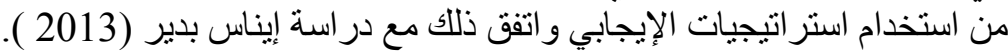

جلول ( 19) الفروق في منتوسط درجات أفراد العينة في استراتيجيات التفاوض تبعا لمتغير العمل

\begin{tabular}{|c|c|c|c|c|c|c|}
\hline الدلالة & قيمة & الحرية & العينة & الالحياري اف & الحسابي & عمل الزوجة \\
\hline \multirow{2}{*}{ لصالح العاملات 0.01} & \multirow{2}{*}{12.054} & \multirow{2}{*}{272} & 158 & $\overline{5.201}$ & 50.338 & تعمل \\
\hline & & & 116 & 3.780 & 38.629 & لا تعمل \\
\hline
\end{tabular}

يتضح من الجدول ( 19) أن قيمة (ت) كانت (12.054) وهى قيمة داملة دالة إحصائيا عند مستوى دلالة (0.01)

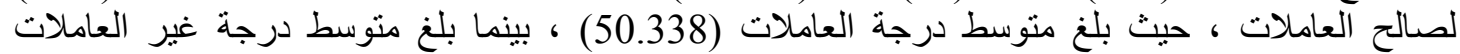

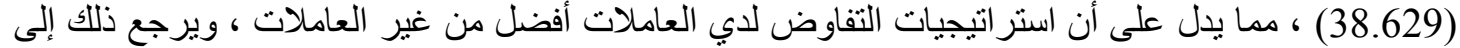

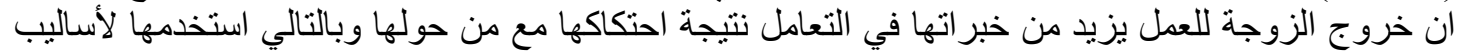
نفاوض إيجابية و اتفق ذلك مع دراسة دعاء دمن عمر وامنية البكري (2021 )

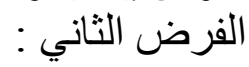
نوجد فروقي ذات دلالة إحصائية بين متوسط درجات أفر اد العينة في ادارة الضغوط الاسرية تبعا لمتغيرات

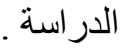

جدول ( 20) تحليل التباين لارجات أفراد العينة في ادارة الضغوط الاسرية تبعا لمتغيرات الدراسة

\begin{tabular}{|c|c|c|c|c|c|}
\hline الدلالة & قيمة (ف) & درجات الحرية & متوسط المربعات & مجموع المربعات & تعليم الزوج \\
\hline \multirow{2}{*}{0.01 دال } & \multirow{2}{*}{37.303} & 2 & 7027.918 & 14055.837 & بين المجمو عات \\
\hline & & 271 & 188.401 & 51056.684 & داخل المجمو عات \\
\hline & & 273 & & 65112.521 & المجموع \\
\hline الدلالة & قيمة (ف) & درجات الحرية & متوسط المربعات & مجموع المربعات & تعليم الزوجة \\
\hline \multirow{2}{*}{0.01 دال } & \multirow{2}{*}{51.949} & 2 & 7335.066 & 14670.131 & بين المجمو عات \\
\hline & & 271 & 141.197 & 38264.330 & داخل المجمو عات \\
\hline
\end{tabular}




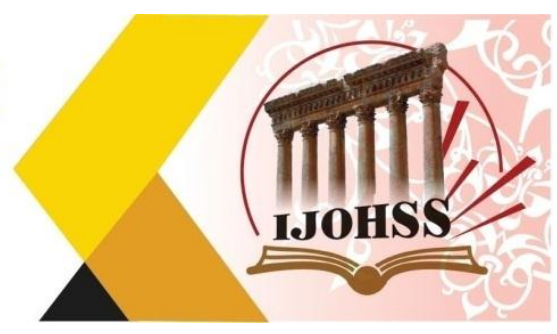

\begin{tabular}{|c|c|c|c|c|c|}
\hline & & 273 & & 52934.461 & المجموع \\
\hline الدلالة & قيمة (ف) & درجات الحرية & متوسط المربعات & مجموع المربعات & مهنة الزوج \\
\hline \multirow{2}{*}{0.01 دال } & \multirow{2}{*}{42.420} & 2 & 7490.337 & 14980.674 & بين المجمو عات \\
\hline & & 271 & 176.574 & 47851.541 & داخل المجمو عات \\
\hline & & 273 & & 62832.215 & المجموع \\
\hline الدلالة & قيمة (ف) & درجات الحرية & متوسط المربعات & مجموع المربعات & مدة الزواج \\
\hline \multirow{2}{*}{0.01 دال } & \multirow{2}{*}{34.855} & 2 & 7019.114 & 14038.229 & بين المجمو عات \\
\hline & & 271 & 201.380 & 54573.884 & داخل المجمو عات \\
\hline & & 273 & & 686612.113 & المجموع \\
\hline الدلالة & قيمة (ف) & درجات الحرية & متوسط المربعات & مجموع المربعات & عدد أفر اد الأسرة \\
\hline \multirow{2}{*}{0.01 دال } & \multirow{2}{*}{61.502} & 2 & 7459.935 & 14919.870 & بين المجمو عات \\
\hline & & 271 & 121.296 & 32871.152 & داخل المجمو عات \\
\hline & & 273 & & 47791.022 & المجموع \\
\hline الدلالة & قيمة (ف) & درجات الحرية & متوسط المربعات & مجموع المربعات & الدخل الشهري \\
\hline \multirow{2}{*}{0.01 دال } & \multirow{2}{*}{28.088} & 2 & 6835.212 & 13670.423 & بين المجمو عات \\
\hline & & 271 & 243.354 & 65948.888 & داخل المجمو عات \\
\hline & & 273 & & 79619.311 & المجموع \\
\hline
\end{tabular}

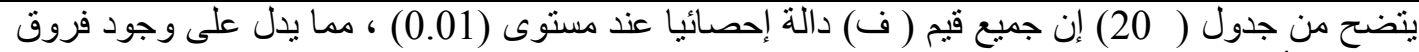

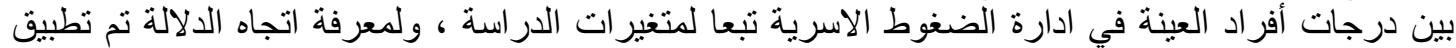

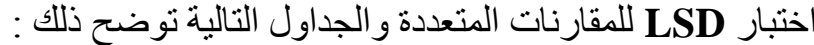
جدول ( 21 ) اختبار LSD للمقارنات المتعددة

\begin{tabular}{|c|c|c|c|}
\hline $\begin{array}{c}\text { م = عالي } 6.358 \\
66.358\end{array}$ & $\begin{array}{c}\text { م = منوسط } 51.295 \\
\text { م }\end{array}$ & م = منخفض 49.029 & تعليم الزوج \\
\hline & & - & منخفض \\
\hline & - & $* 2.266$ & متوسط \\
\hline - & $* * 15.063$ & $* * 17.329$ & عالي \\
\hline
\end{tabular}

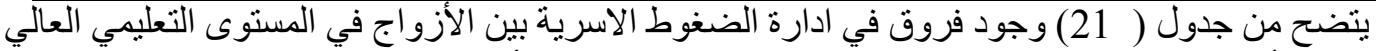

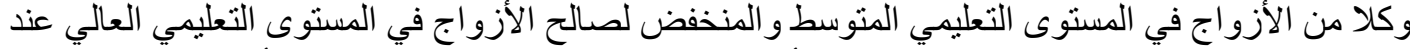

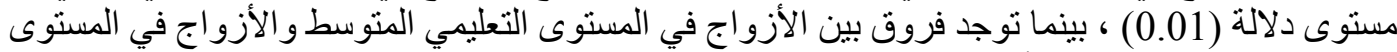

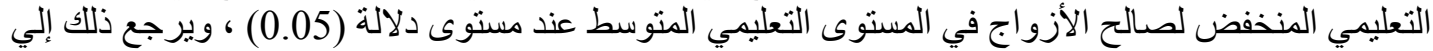

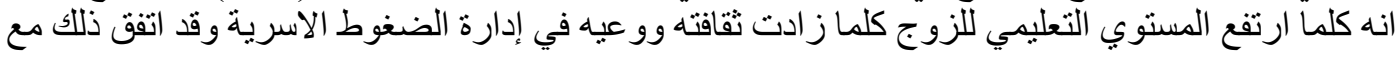

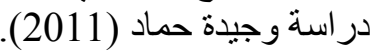

جدول ( 22 ) اختبار LSD للمقارنات المتعددة

\begin{tabular}{|c|c|c|c|}
\hline 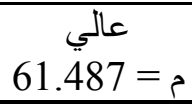 & م = متوسط 50.441 م0.4 & م = منخفض 42.293 & تعليم الزوجة \\
\hline & & - & منخفض \\
\hline & - & $* * 8.148$ & متوسط \\
\hline
\end{tabular}




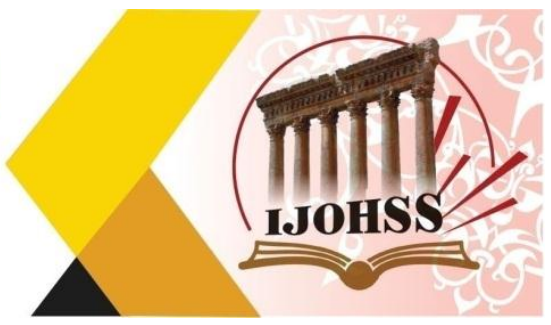

\section{\begin{tabular}{l|l}
$* * 11.046$ & $* * 19.194$ \\
\hline
\end{tabular}}

عالي

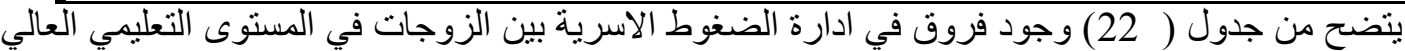

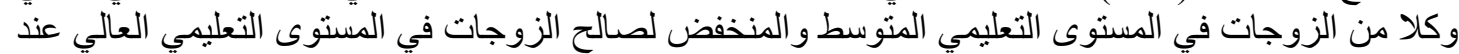

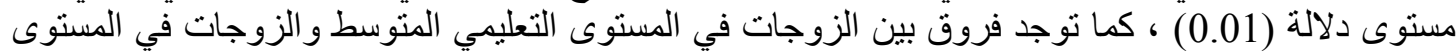

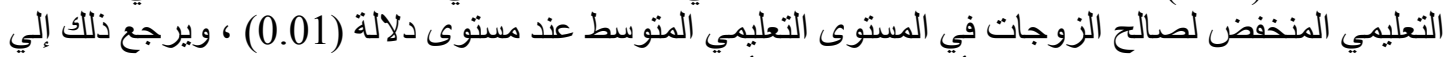

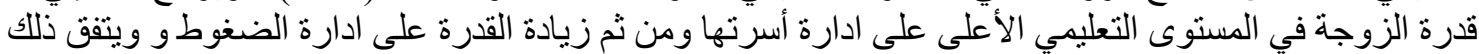

( Abdel Ghany , 1999)

جدول ( 23 ) اختبار LSD للمقارنات المتعددة

\begin{tabular}{|c|c|c|c|}
\hline م = أعمال حرة & 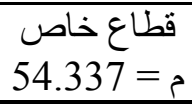 & وظيفة حكومية & مهنة الزوج \\
\hline & & - & وظيفة حكو مية \\
\hline & - & $* * 13.732$ & قطاع خاص \\
\hline - & $* * 12.129$ & $* * 25.861$ & أعمال حرة \\
\hline
\end{tabular}

يتضح من جدول ( 23) وجود فروق في ادارة الضغوط الاسرية بين الأزواج العاملين بالوظائف الحكومية وكلا

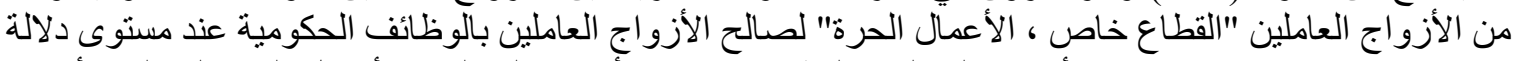

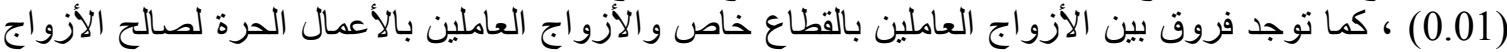

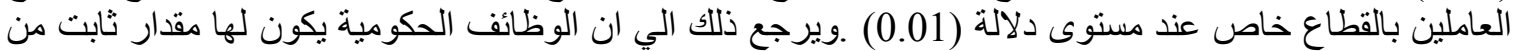
الدخل شهريا ولا يفكر الزوج في المشكلات الاقتصادية بشكل دائم و التي تكون من الأسباب الرئيسة لعدم إدارة

جدول (24) اختبار LSD للمقارنات المتعددة

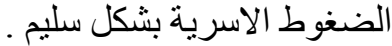

\begin{tabular}{|c|c|c|c|}
\hline من مأكثر 10 سنو ات & من 5 سنوات لأقل 10 سنوات & مأقل من 5 من 5 & مدة الزواج \\
\hline & & - & أقل من 5 سنو ات \\
\hline & - & $* 2.332$ & من 5 سنوات لأقل من 10 سنوات \\
\hline - & $* * 17.006$ & $* * 19.338$ & من 10 سنو ات فأكثر \\
\hline
\end{tabular}

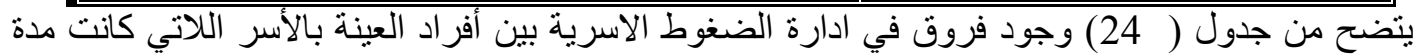

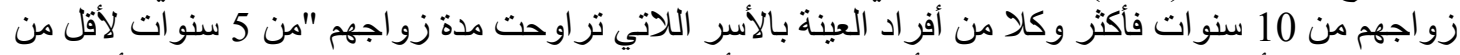

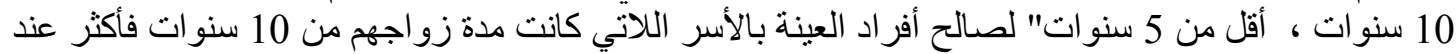

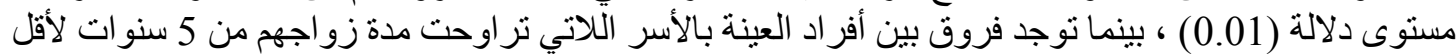

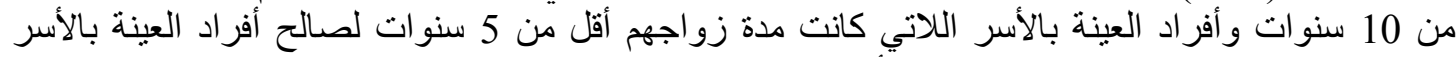

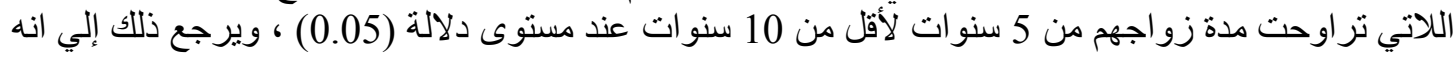

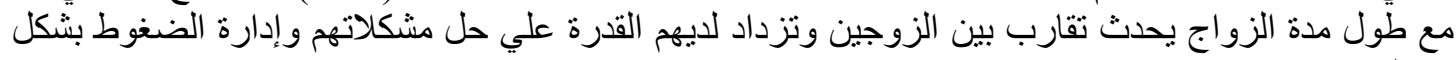

جدول ( 25) اختبار LSD للمقارنات المتعددة

\begin{tabular}{|c|c|c|c|}
\hline من 6 أفر اد فأكثر & 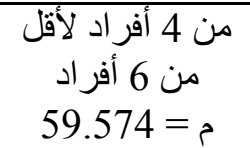 & أقل من 4 أفر اد 70.112 & عدد أفر اد الأسرة \\
\hline & & 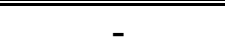 & أقلّل من 4 أفر اد \\
\hline & - & $* * 10.538$ & من 4 أفر اد لأقَل من 6 أفر اد \\
\hline
\end{tabular}




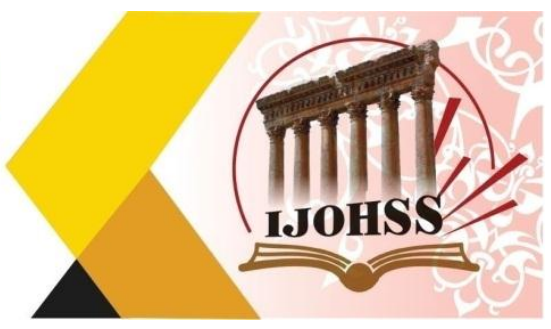

$* * 13.239$ $* * 23.777$

من 6 أفر اد فأكثر

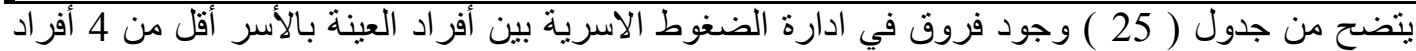

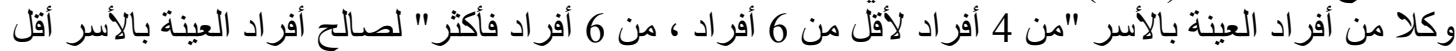

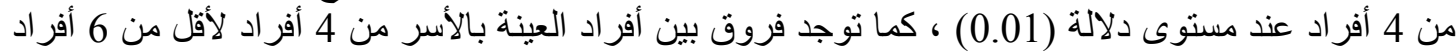

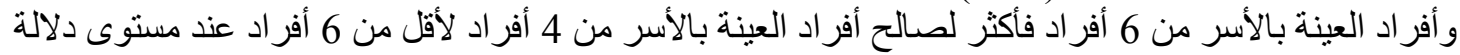

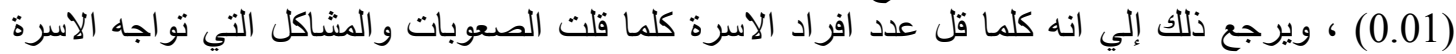

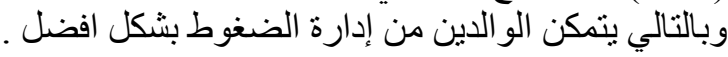
جذول ( 26 ) اختبار LSD للمقارنات المتعددة

\begin{tabular}{|c|c|c|c|}
\hline م = مرتفع & م = متوسط 48.273 & م = منخفض & الدخل الثهري \\
\hline & & - & منخفض \\
\hline & - & $* 2.166$ & متوسط \\
\hline- & $* * 11.889$ & $* * 14.055$ & مرتفع \\
\hline
\end{tabular}

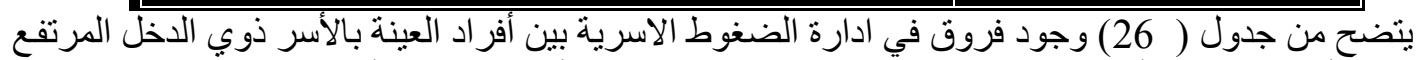

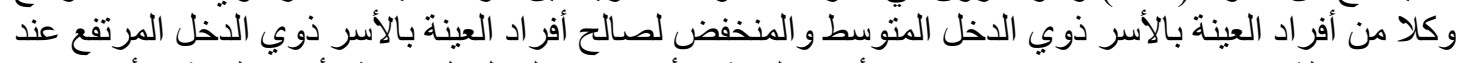

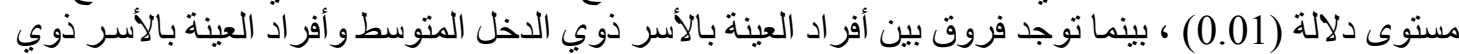

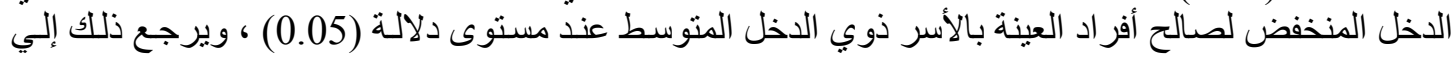

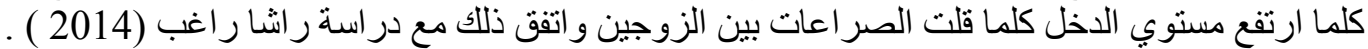

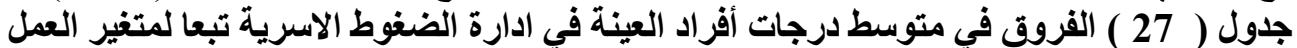

\begin{tabular}{|c|c|c|c|c|c|c|}
\hline الدلالة & (تيمة & الحربة & العينة & الانحراف & الحستوسط & عمل الزوجة \\
\hline \multirow{2}{*}{ لصالح العاملات 0.01} & \multirow{2}{*}{19.335} & \multirow{2}{*}{272} & 158 & $\overline{6.293}$ & 765.558 & تعمل \\
\hline & & & 116 & 4.335 & 44.029 & لا تعمل \\
\hline
\end{tabular}

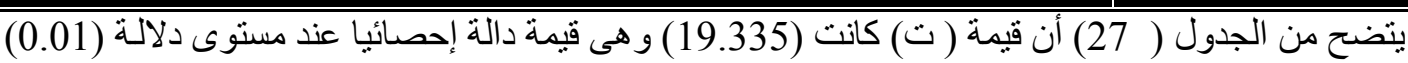

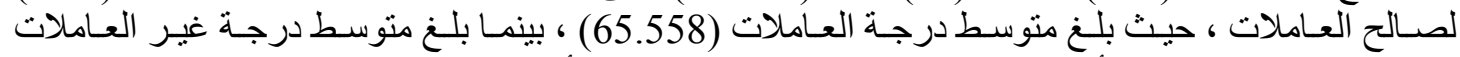

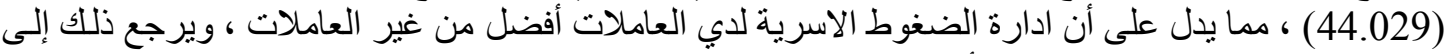

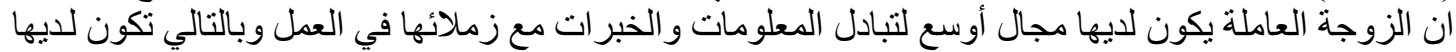
القدرة علي مواجهة إدارة الضغوط الاسرية واتفق ذلك مع در اسة هند السيد (2017 ) وشرين محفوظ (2015) .

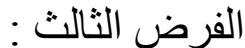

توجد علاقة ارتباطية بين محاور استبيان استر اتيجيات التفاوض ومحاور التبان استبيان ادارة الضغوط الاسرية

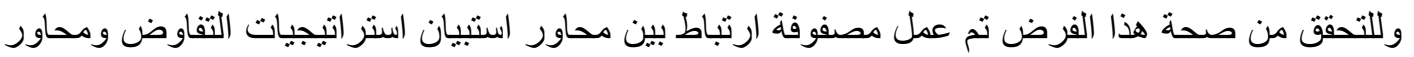

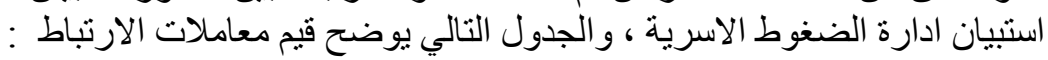

جدول ( 28) مصفوفة الارتباط بين محاور استبيان استراتيجيات

التفاوض ومحاور استبيان ادارة الضغوط الإنيان الاسرية التئية

\begin{tabular}{|c|c|c|c|c|}
\hline الاسرية ككل الضغوة & الضنغية الضفية & الضنغوط المادية & الاجنماعية & \\
\hline$* * 0.851$ & $* * 0.812$ & $* * 0.781$ & $* * 0.707$ & التفاوض الايجابي \\
\hline$* * 0.745$ & $* 0.601$ & $* * 0.914$ & $* * 0.834$ & الثبات الانفعالي \\
\hline
\end{tabular}


المجلة اللحولية اللملوم الآنسانية والإمتماعية International Journal on Humanities and Social Sciences website:www.ijohss.com Email:editor@ijohss.com العدد (30) فبراير 2022 ISSN: $2415-4822$ Volume (30) February 2022

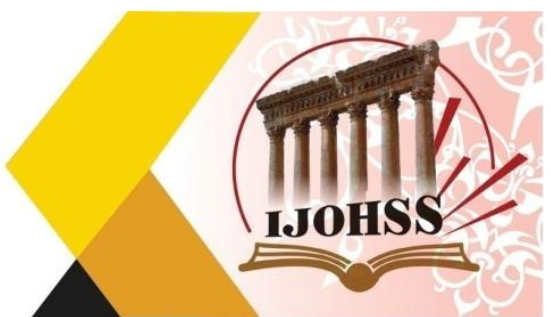

\begin{tabular}{|c|c|c|c|c|}
\hline$* * 0.777$ & $* * 0.945$ & $* * 0.888$ & $* 0.640$ & التعاون المشترك \\
\hline$* * 0.890$ & $* * 0.725$ & $* * 0.840$ & $* * 0.766$ & التفاوض السلبي \\
\hline$* * 0.794$ & $* * 0.871-$ & $* * 0.926$ & $* 0.627-$ & السلطة و الاجبار \\
\hline$* * 0.826-$ & $* * 0.756$ & $* 0.611-$ & $* * 0.908$ & الانسحاب و الانعز ال \\
\hline$* * 0.735$ & $* * 0.847$ & $* * 0.808$ & $* * 0.863$ & استبيان استر اتيجيات التفاوض ككل \\
\hline
\end{tabular}

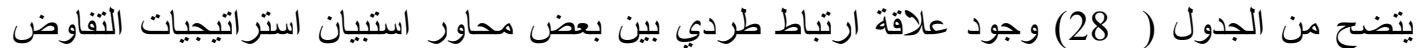

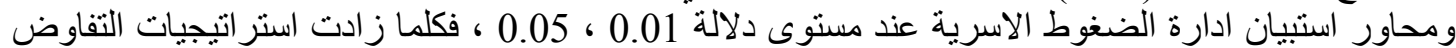

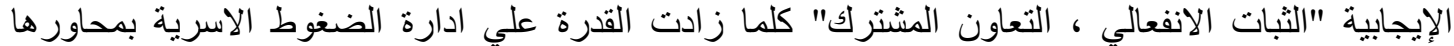

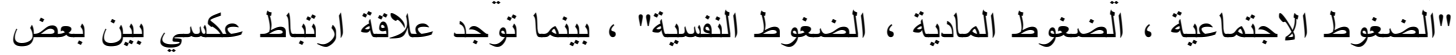

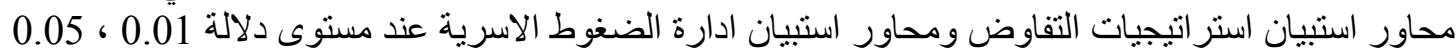

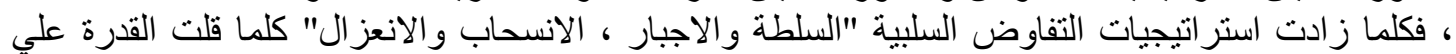

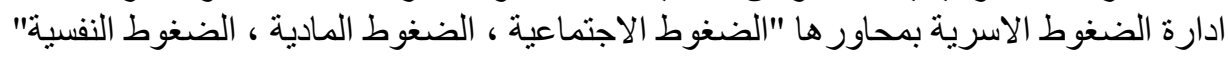

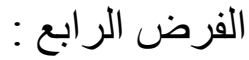

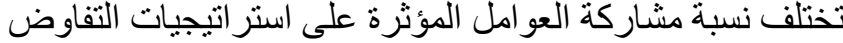

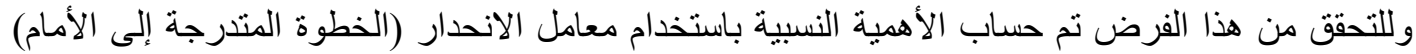

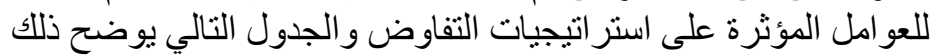
جدول ( 29) الأهمية النسبية باستخدام معامل الانحدار (الخطوة المتدرجة إلى الأمام) اللعو امل المؤثرة على استراتيجيات التفاوض الانيار الخطوة

\begin{tabular}{|c|c|c|c|c|c|c|c|c|}
\hline الدلالة & قيمة (ت) & الانحدار & الدلالة & قيمة (ف) & المشناركة & الارتباط & المتغير المستقل & \\
\hline 0.01 & 11.544 & 0.701 & 0.01 & 133.271 & 0.826 & 0.909 & تعليم الزوج & \\
\hline 0.01 & 9.374 & 0.615 & 0.01 & 87.875 & 0.758 & 0.871 & مدة الزواج & \\
\hline 0.01 & 7.859 & 0.532 & 0.01 & 61.770 & 0.688 & 0.830 & مهنة الزوج & \\
\hline 0.01 & 6.943 & 0.469 & 0.01 & 48.202 & 0.633 & 0.795 & تعليم الزوجة & \\
\hline
\end{tabular}

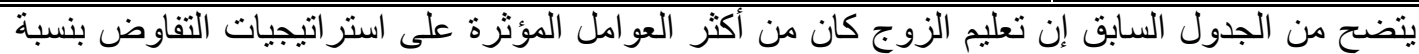

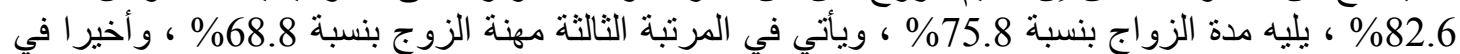
المرتبة الر ابعة تعليم الزوجة بنسبة 63.3\% \%

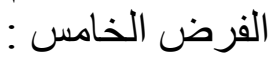

تختلف نسبة مشاركة العو امل المؤثرة على ادارة الضغوط الأسرية

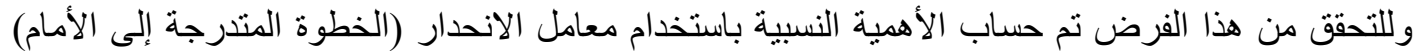

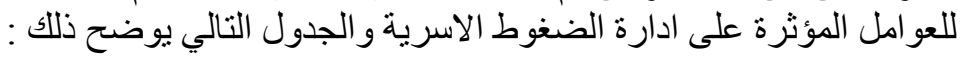

جدول ( 30) الأهمية النسبية باستخدام معامل الاتحدار (الخطوة المتدرجة إلى الأمام)

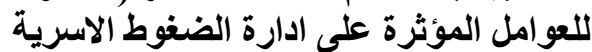

\begin{tabular}{|c|c|c|c|c|c|c|c|c|}
\hline الدلالة & قيمة (ت) & الانحدار & الدلالة & قيمة ( ف) & المشاركة & الارتباط & المتغير المستقل & \\
\hline$\overline{0.01}$ & 10.353 & 0.658 & $\overline{0.01}$ & 107.176 & 0.793 & 0.890 & تعليم الزوجة & \\
\hline 0.01 & 8.544 & 0.572 & 0.01 & 72.998 & 0.723 & 0.850 & تعليم الزوج & \\
\hline
\end{tabular}


website:www.ijohss.com

Email:editor@ijohss.com

ISSN: $2415-4822$
العداد (30) مبراير 2022

Volume (30) February 2022

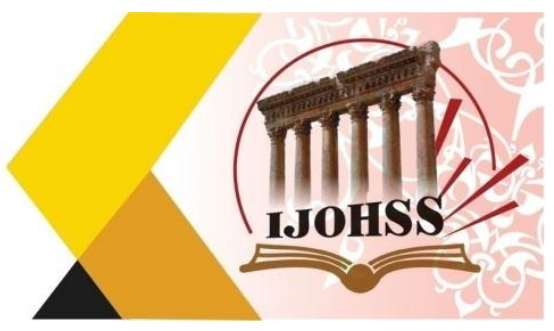

\begin{tabular}{|c|c|c|c|c|c|c|c|}
\hline 0.01 & 7.372 & 0.502 & 0.01 & 54.353 & 0.660 & 0.812 & مهنة الزوج \\
\hline 0.01 & 6.238 & 0.413 & 0.01 & 38.910 & 0.582 & 0.763 & مدة الزواج \\
\hline
\end{tabular}

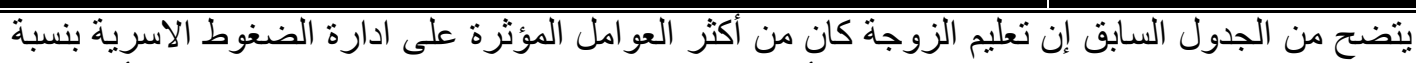

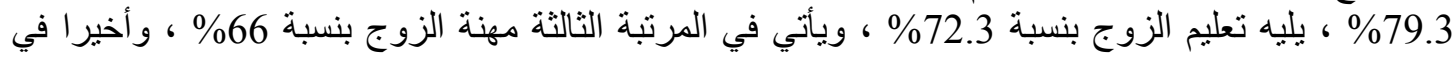

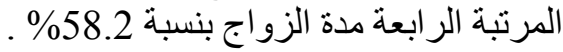

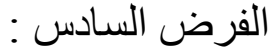

تختلف الأوزان النسبية لأولوية أبعاد استر اتيجيات التفاوض لأفر اد عينة البحث

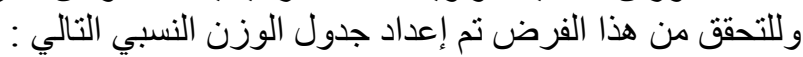

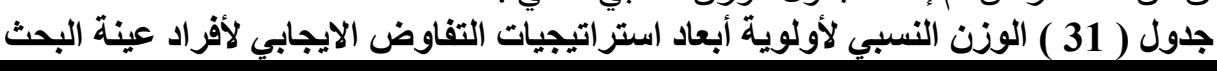

\begin{tabular}{|c|c|c|c|}
\hline الترتيب & النسبة المئوية\%\% & الوزن النسبي & استر اتيجيات التفاوض الايجابي \\
\hline الأول & \%52.7 & 330 & الثبات الانفعالي \\
\hline 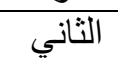 & $\% 47.3$ & 296 & التعاون المشتركَّ \\
\hline & $\% 100$ & 626 & المجموع \\
\hline
\end{tabular}

يتضح من الجدول أن أولوية أبعاد استر اتيجيات التفاوض الايجابي لأفر اد عينة البحث كان الثبات الانفعالي بنسبة

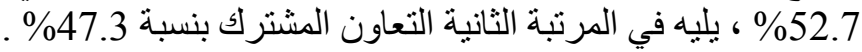

جدول ( 32 ) الوزن النسبي أكثر أبعاد استراتيجيات التفاوض السلبي لأقراد عينة البحث

\begin{tabular}{|c|c|c|c|}
\hline الترتيب & النسبة المئويةه\% & الوزن النسبي & استر اتيجيات التفاوض السلبي \\
\hline الأول & $\% 55.1$ & 354 & الانسحاب و الانعز ال \\
\hline 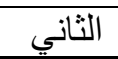 & $\% 44.9$ & 288 & السلطة و الاجبار \\
\hline & $\% 100$ & 642 & المجموع \\
\hline
\end{tabular}

بتضح من الجدول أن أكثر أبعاد استر اتيجيات التفاوض السلبي لأفراد عينة البحث كان الانسحاب و الانعز ال

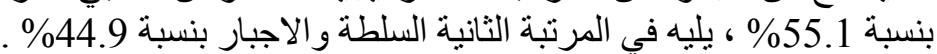

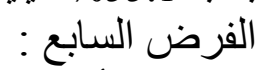

تختلف الأوزان النسبية لأولوية أبعاد ادارة الضغوط الإسرية لأفر اد عينة البحث

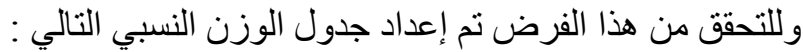

جدول ( 33) الوزن النسبي لأولوية أبعاد ادارة الضغوط الضوط الاسرية لأفراد عينة البحث

\begin{tabular}{|c|c|c|c|}
\hline الترتيب & النسبة المئوية\%\% & الوزن النسبي & ادارة الضغوط الاسرية \\
\hline الأول & $\overline{\% 36.4}$ & 372 & الضغوط المادية \\
\hline الثاني & $\% 34.1$ & 349 & الضغوط النفسية \\
\hline الثالث & $\% 29.5$ & 301 & الضغوط الاجتماعية \\
\hline & $\% 100$ & $\overline{1022}$ & المجموع \\
\hline
\end{tabular}

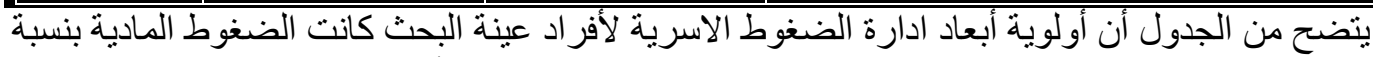

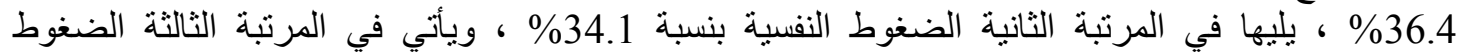

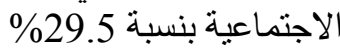

$$
\text { توصيات البحث : }
$$

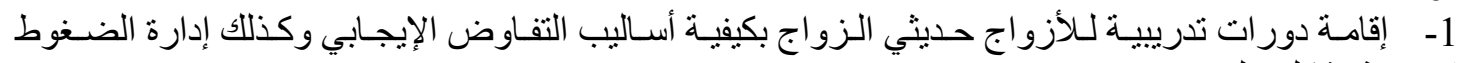
الاسرية بشكل علمي . 


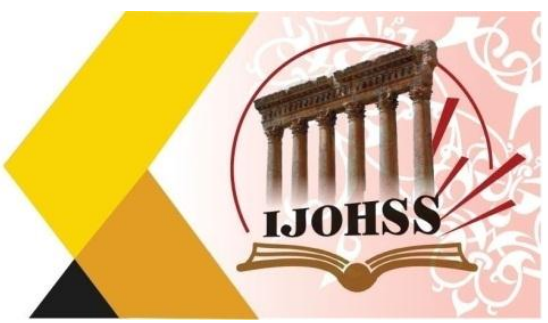

2- إجر اء المزبـد من الدراسـات و البحوث التي تتنـاول استر اتيجيات التفـاوض علي أسس علميـة لدعم التو افق

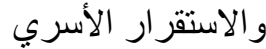
3ـ التركيز من وسائل الاعلام المختلفة علي بر امج الارشاد الزو اجي لمـا لـه من أهميـة كبيرة في إدارة الضـغوط

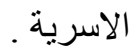

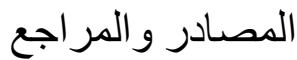
1-.ابتسام بوسف محمد مرزوق (2011) : استر اتيجيات إدارة الصر اع التي تبعها مدبرو مدارس وكالة القوات

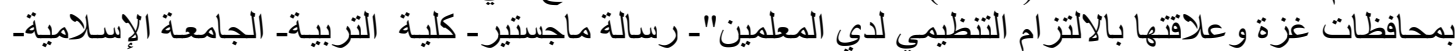
غزة.

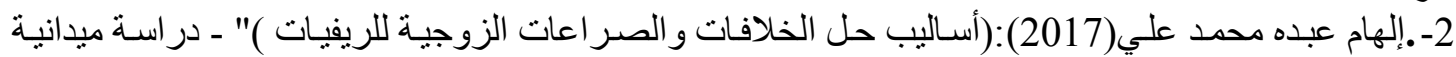

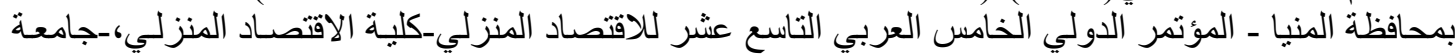

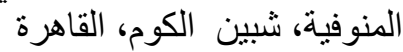

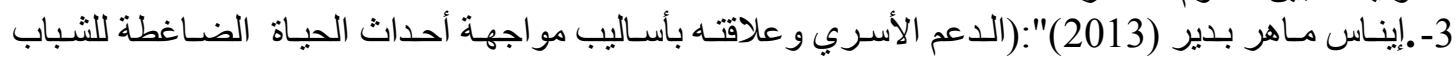

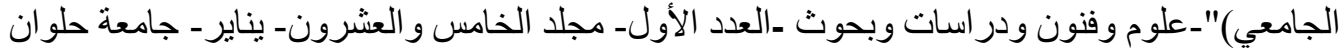

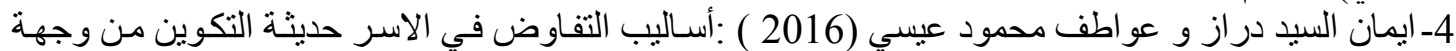

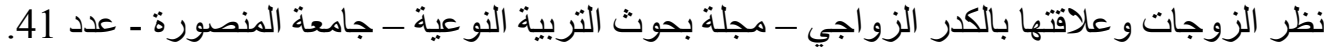

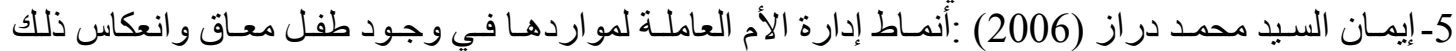

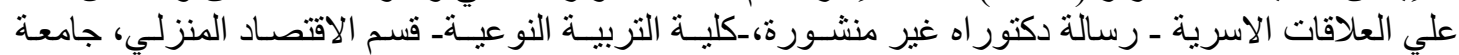

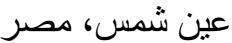
6- ثابت عبد الرحمن إدريس (2001) " :(التفاوض مهار ات و استر اتيجيات "ـ الدار الجامعيـة للنشر و التوزيع-

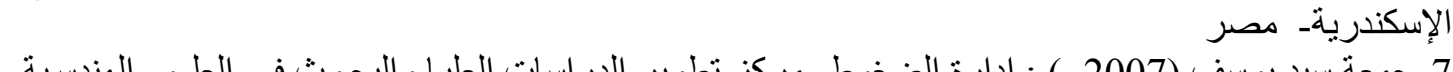
7-جمعة سيد يوسف (2007 ) ) : إدارة الضغوطــ مركز تطوير الدراسات العليا و البحوث في العلـوم الهندسيةالطبعة الأولى- جامعة القاهرة- القاهرة.

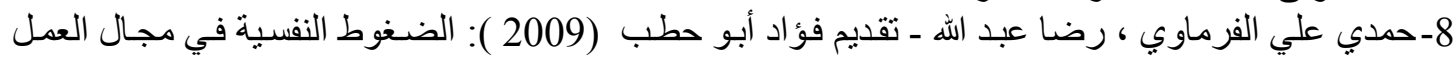

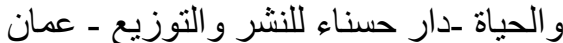

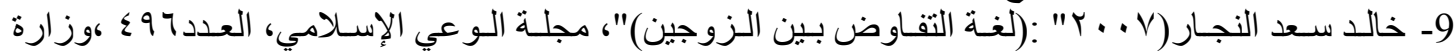
الأوقاف و التشئون الإسلامية، الكويت.

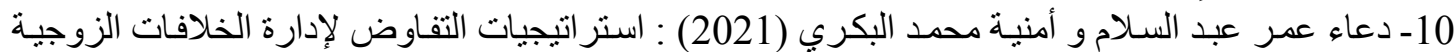

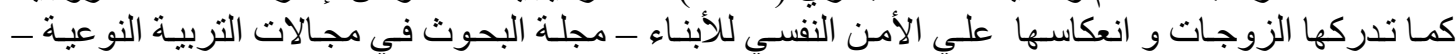

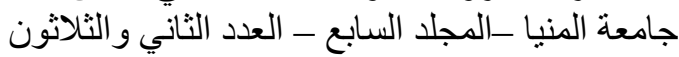

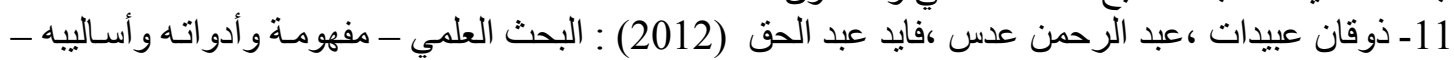

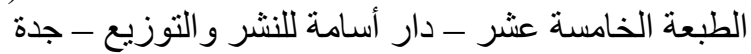

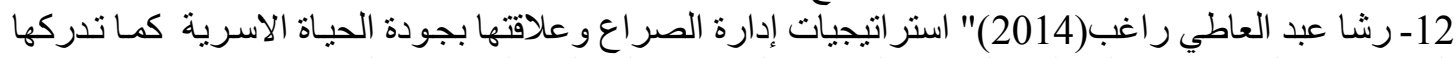

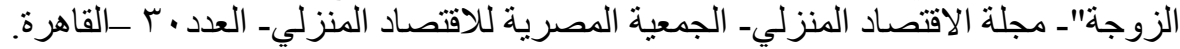

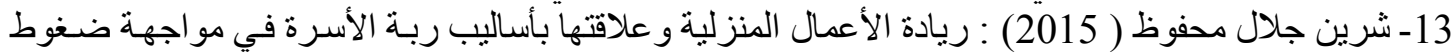

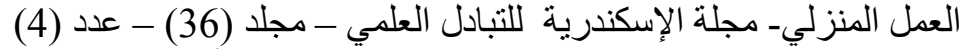

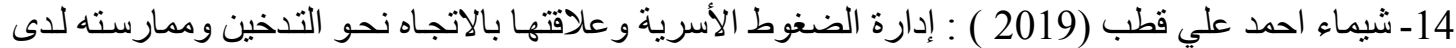

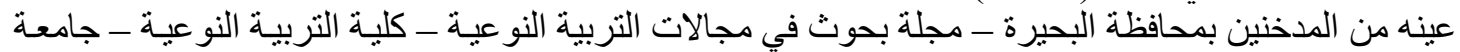

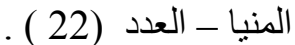

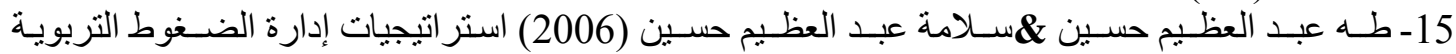

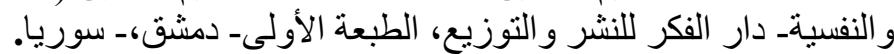

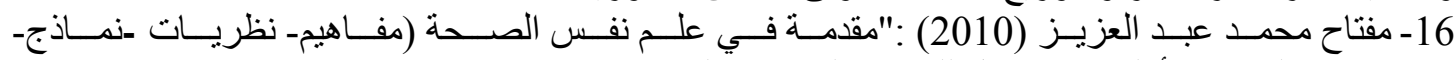

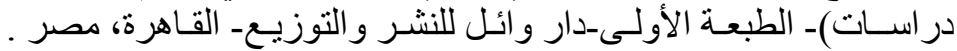

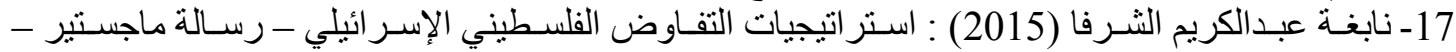




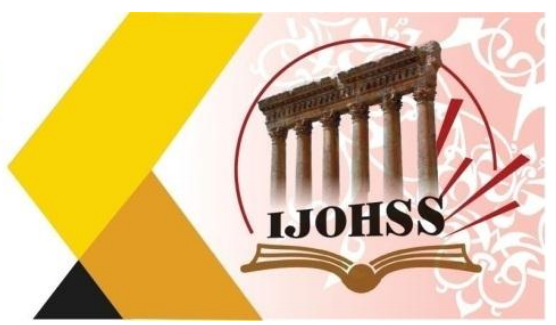

اكاديمية الإدارة و السياسة للار اسات العليا - غزة - فلسطين

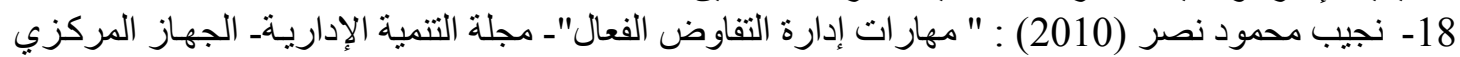

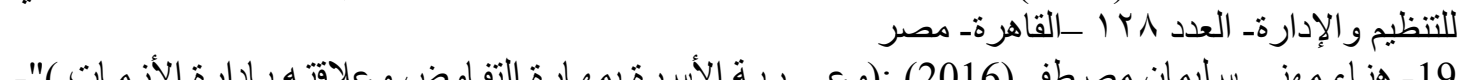

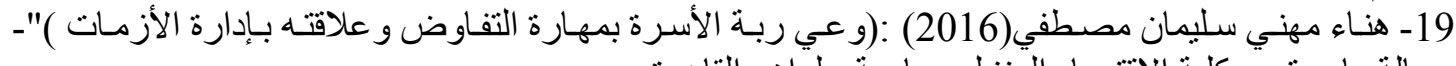

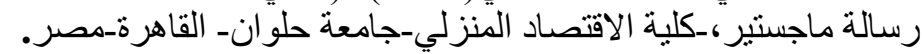

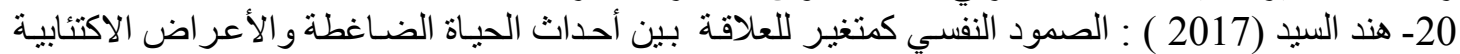
لادي الار امل -رسالة ماجستير -جامعة سو هاج

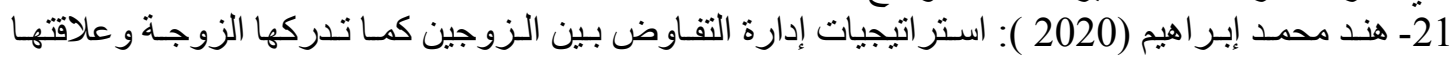

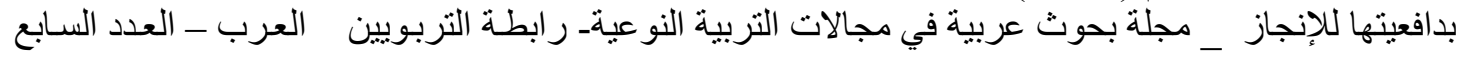

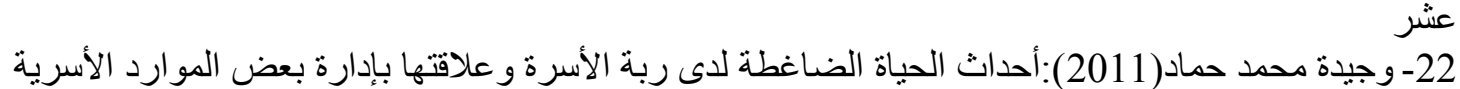

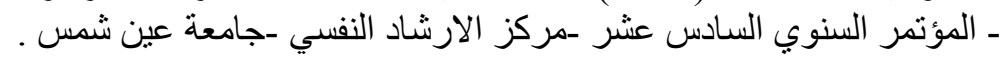
23-Abdel Ghan ,M .\& Foster,A.(1999):Impact of income and wife ,s education on family consumption expenditure ,journal of consumer studies and Home Economics .vol.6.No(3) .

24 -Benner, Aprile D.Kim ,Sm Yeong (2010) "Understanding Chinese American adolescents developmental outcomes journal of research on adolescence Wiley black well

25- Conger, Rand, wallance, Lora\&Sun, Yumei(2002) 'Economics pressure in African American families : Areplication and extension of the family stress Model' Developmental Psychology, Vol.38(2), March pp.179-193.

26- Radcliff, p.(2011):" Motherhood, Pregnancy , and the negotiation of identity :the moral career if drug treatment, Journal of Experimental Social Psychology 72,987991.

27- Saber, Mohamed Ahmed. (2012). The foundations of the negotiation process, building an effective negotiator. Anglo-Egyptian, Cairo, Egypt.

28- Sadeeq, Afifi \& Mostafa, Abu Bakr. (2011). Negotiated in life and business practical guide. Third Edition, University House, Egypt

29- Wasti ,S.A\& Cortina, L.N. (2002):" Coping in Contexet" Socioultural Determinants of Responses to Sexual Harassment". Journ al of Personality and Social Psychology,83(2)394-405 . 